$$
\begin{array}{ccccccc}
\text { L } & \text { E } & \text { T } & \text { u } & \text { v } & \text { о } & \text { s } \\
\hline \text { ARCHEOlogija } & 47
\end{array}
$$



Lietuvos istorijos institutas

\begin{tabular}{llllllll}
$\mathrm{L}$ & $\mathrm{I}$ & $\mathrm{E}$ & $\mathrm{T}$ & $\mathrm{U}$ & $\mathrm{V}$ & $\mathrm{O}$ & $\mathrm{S}$ \\
\hline
\end{tabular}

ARCHEOlogija 47 


\section{Leidybą finansavo}

\section{LIETUVOS MOKSLO TARYBA}

PAGAL VALSTYBINĘ LITUANISTINIŲ TYRIMŲ IR SKLAIDOS 2016-2024 METŲ PROGRAMĄ

(Finansavimo sutarties numeris S-LIP-19-4)

\section{Redaktorių kolegija / Editorial board:}

Atsakingoji redaktorė / Editor-in-chief dr. Agnè Čivilytė (Lietuvos istorijos institutas, Vilnius / Lithuanian Institute of History, Vilnius)

Atsakingosios redaktorès pavaduotoja / Assistant Editor dr. Elena Pranckènaitè (Lietuvos istorijos institutas, Vilnius / Lithuanian Institute of History, Vilnius)

Dr. Laurynas Kurila (Lietuvos istorijos institutas, Vilnius / Lithuanian Institute of History, Vilnius)

Dr. Valdis Bērziņš (Latvijos universitetas, Latvijos istorijos institutas, Ryga / University of Latvia, Institute of Latvian History, Riga)

Habil. dr. Anna Bitner-Wróblewska (Valstybinis archeologijos muziejus Varšuvoje, Lenkija / State Archaeological Museum in Warsaw, Poland)

Dr. Christoph Jahn (Baltijos ir Skandinavijos archeologijos centras, Šlèzvigas, Vokietija / Center for Baltic and Scandinavian Archaeology, Schleswig, Germany)

Prof. dr. Rimantas Jankauskas (Vilniaus universitetas, Lietuva / Vilnius University, Lithuania)

Akad. prof. dr. Eugenijus Jovaiša (Lietuvos mokslu akademija, Vilnius / Lithuanian Academy of Sciences, Vilnius)

Habil. dr. Bartosz Kontny (Varšuvos universitetas, Archeologijos fakultetas, Lenkija / Faculty of Archaeology, University of Warsaw, Poland)

Prof. dr. Valter Lang (Tartu universitetas, Estija / University of Tartu, Estonia)

Doc. dr. Algimantas Merkevičius (Vilniaus universitetas, Lietuva / Vilnius University, Lithuania)

Habil. dr. Tomasz Nowakiewicz (Varšuvos universitetas, Archeologijos fakultetas, Lenkija / Faculty of Archaeology, University of Warsaw, Poland)
Habil. dr. Grzegorz Osipowicz (Mikalojaus Koperniko universitetas, Torunè, Lenkija / Nicolaus Copernicus University, Toruń, Poland)

Dr. Gytis Piličiauskas (Lietuvos istorijos institutas, Vilnius / Lithuanian Institute of History, Vilnius)

Dr. Eve Rannamäe (Tartu universtitetas, Estija / University of Tartu, Estonia)

Dr. Andra Simniškyte (Lietuvos istorijos institutas, Vilnius / Lithuanian Institute of History, Vilnius)

Dr. Roberts Spirgis (Latvijos universitetas, Latvijos istorijos institutas, Ryga / University of Latvia, Institute of Latvian History, Riga)

Dr. Eugenijus Svetikas (Lietuvos istorijos institutas, Vilnius / Lithuanian Institute of History, Vilnius)

Dr. Andris Šnē (Latvijos universitetas, Ryga / University of Latvia, Riga)

Doc. dr. Gintautas Zabiela (Klaipédos universitetas, Lietuva / Klaipéda University, Lithuania)

Prof. dr. Šarūnas Milišauskas (Niujorko valstijos Bafalo universitetas, JAV / New York State University at Buffalo, USA)

Prof. dr. Timothy Chevral (Niujorko valstijos Bafalo universitetas, JAV / New York State University at Buffalo, USA)

Prof. dr. Johan Ling (Gioteborgo universitetas, Švedija / University of Gothenburg, Sweden)

Sekretorè / Secretary Dovilè Urbonavičiūtė-Jankauskienė

Redakcijos adresas / Editorial Board address:

Lietuvos istorijos institutas, Archeologijos skyrius

Tilto g. 17, LT-01101 Vilnius

Tel. (+370) 5 2614436, fax (+370) 52611433

e-mail: lietuvosarcheologija@gmail.com; civilytea@gmail.com

\section{Žurnalas registruotas: EBSCO Publishing: Central and Eastern European Academic Source European Reference Index for the Humanities and Social Sciences (ERIH PLUS)}




\section{TURINYS / CONTENT}

Agnè Čivilytė

Ernestine S. Elster

James Patrick Mallory
PRATARME் 7

FOREWORD 11

\section{MARIJA GIMBUTIENE் KAIP ASMENYBE் / MARIJA GIMBUTAS AS PERSONALITY}

MARIJA GIMBUTAS, HER EXCAVATIONS, AND THE CONCEPT OF OLD EUROPE / MARIJA GIMBUTIENĖ, ARCHEOLOGINIAI KASINĖJIMAI IR SENOJI EUROPA .15

MARIJA GIMBUTAS IN THE CLASSROOM, FIELD AND OFFICE: A SHORT PERSONAL REMINISCENCE / MARIJA GIMBUTIENE KLASĖJE, KASINĖJIMUOSE IR KABINETE: TRUMPI ASMENINIAI PRISIMINIMAI .31

Kornelija Jankauskaitė MARIJA GIMBUTIENÉ: KELIAUTOJA IR TYRĖJA / MARIJA GIMBUTAS: TRAVELLER AND RESEARCHER .43

\section{STRAIPSNIAI / ARTICLES}

Šarūnas Milišauskas MARIJA GIMBUTAS (GIMBUTIENĖ): THE BALTIC GODDESS .55 MARIJA GIMBUTIENĖ: BALTŲ DEIVE். .88

Julia Mattes

ANTHROPOMORPHIC FIGURINES, GYNOCENTRISM AND GIMBUTAS' RECEPTION INSIDE ARCHAEOLOGY AND BEYOND .91

ANTROPOMORFINĖS FIGŪRĖLĖS, GINOCENTRIZMAS IR MARIJOS GIMBUTIENĖS IDĖJOS ARCHEOLOGIJOJE BEI UŽ JOS RIBŲ 123

MELLAART, GIMBUTAS, GODDESSES, AND ÇATALHÖYÜK: EARLY ASSUMPTIONS AND RECENT PERSPECTIVES ON THE ÇATALHÖYÜK FINDS 125

MELLAARTAS, GIMBUTIENĖ, DEIVĖS IR ČATAL HIUJUKAS: PIRMOSIOS PRIELAIDOS IR NAUJAUSIA RADINIŲ IŠ ČATAL HIUJUKO APŽVALGA 143 
Sharada Srinivasan

Rasa Banytè-Rowell

Florin Gogâltan

Gytis Piličiauskas Edvardas Simčenka Justina Kozakaitè Žydrūnè Miliauskienė Giedrè Piličiauskienè Harry Kenneth Robson

Janusz Czebreszuk Agnè Čivilytė

Paulius Gritènas

Artūras Dubonis
GODDESS WORSHIP AND THE DANCING FORM: EXPLORING RITUAL IN INDIAN PREHISTORY AND SOUTH INDIAN ANTIQUITY 145 DEIVĖS GARBINIMAS IR ŠOKIO JUDESIO FORMA: RITUALAI INDIJOS PRIEŠISTORĖJE IR PIETŲ INDIJOS ANTIKOJE 164

MARIJA GIMBUTAS’ DISSERTATION AND ITS VALUE:

BURIAL CUSTOMS IN THE ROMAN IRON AGE. 167 MARIJOS GIMBUTIENĖS DISERTACIJA IR JOS SVARBA: ROMĖNIŠKOJO LAIKOTARPO LAIDOSENA 185

TRANSYLVANIA AND THE OF INDO-EUROPEAN MIGRATION PROBLEM. THE ROMANIAN PARADIGM 187 TRANSILVANIJA IR INDOEUROPIEČIŲ MIGRACIJOS PROBLEMA. RUMUNIJOS PARADIGMA 207

DONKALNIO IR SPIGINO KAPINYNŲ AKMENS AMŽIAUS ŽMONIŲ KILMÉ IR MOBILUMAS STRONCIO IZOTOPŲ ANALIZĖS DUOMENIMIS. 209

THE ORIGINS AND MOBILITY PATTERNS OF STONE AGE HUMANS FROM THE DONKALNIS AND SPIGINAS BURIAL GROUNDS ACCORDING TO STRONTIUM ISOTOPE ANALYSIS. . .232

PROFESSOR MARIJA GIMBUTAS' ADVENTURE WITH PREHISTORIC AMBER AND THE RESULTS FOR US. 235 MARIJOS GIMBUTIENÉS PRIEŠISTORINIO GINTARO TYRINĖJIMAI IR JŲ REIKŠMĖ ŠIANDIEN 247

\section{KITAIP APIE ARCHEOLOGIJĄ /} ALTERNATIVE PERCEPTIONS OF ARCHAEOLOGY

FILOSOFIJA KAIP ARCHEOLOGIJA 249

\section{RECENZIJOS / REVIEWS}

RYTIS JONAITIS, IRMA KAPLŪNAITE்.

SENKAPIS VILNIUJE, BOKŠTO GATVËJE. XIII-XV A.

LAIDOSENOS LIETUVOJE BRUOŽAI. .253

AUTORIŲ DE்MESIUI 259

GUIDELINES FOR AUTHORS 263 


\title{
ANTHROPOMORPHIC FIGURINES, GYNOCENTRISM AND GIMBUTAS' RECEPTION INSIDE ARCHAEOLOGY AND BEYOND
}

\author{
JULIA MATTES
}

Institutionen för arkeologi och antik historia, Box 626, S-751 26 Uppsala, e-mail: julia.mattes@rub.de

Gimbutas' topicalisation of gynocentrism was of great significance in stimulating the study of figurines, influencing the humanities beyond archaeology, as well as a variety of international socio-political movements.

The creations have a long tradition of being linked to fertility and suffer a predominantly onesided treatment in research. In this context, the intellectual history of the interpretation of prehistoric social living conditions is analysed, critically questioned and the extent to which historically evolved role models are present in past and recent research is examined. On the basis of selected examples, the methods of ethnological analogy and stylistic analysis are used to contribute to the interpretation of the decorations of the SE European Neolithic material. Additionally, an application-related interpretation is proposed for the Cucuteni-Tripolye figurines of the Poduri set.

The second part addresses the impact history of Gimbutas' opus. Regardless of the justified methodological criticism, its various imprints on e. g. ethnography, feminist studies, as well as outside academia will be acknowledged. The contributions profoundly inspired a variety of societal currents in the USA, Germany and post-socialist Lithuania.

Keywords: Gimbutas, Lithuania, figurines, tattoo, body modification, ancestors, feminist movement.

Savo darbais Marija Gimbutienè ginocentrizma iškèlè kaip svarbia tema, ir tai lèmé padidejusị susidomèjima figūrèliu tyrimais archeologijoje bei kitose disciplinose, taip pat turéjo poveiki ịvairiu tarptautiniu sociopolitiniu judejimu iškilimui.

M. Gimbutienès darbuose aptariami dirbiniai tradiciškai siejami su vaisingumu ir būdavo tiriami tik vienpusiškai. Šiame straipsnyje atsižvelgiama ị pastaraji konteksta norint išnagrinèti priešistorès gyvenimo salygu interpretavimo istorija. Taip pat kritiškai peržvelgiamas klausimas, susijęs su istorijos eigoje susidariusiais lyčiu vaidmenimis, kurie gyvavo tiek ankstesniuose tyrimuose, tiek gyvuoja ir šiandien.

Pietryčiu Europos neolito laikotarpio archeologinès medžiagos ornamentika interpretuojama pasitelkiant etnologiniu analogu paieškas ir stiliaus analizę. Taip pat autore aprašo Kukutenio-Tripolès kultūros Poduri-Dealul figūrèlių rinkinị ir pateikia figūrèlių reikšmès interpretaciją.

Antroje straipsnio dalyje autoré sutelkia demesi $i$ M. Gimbutienès darbų ịtaka etnografijai, feminizmui ir kitoms akademinems kryptims. Nepaisant pagristos kritikos, susijusios su metodologija, pripažistama, jog M. Gimbutienès darbai ne tik turejo ịtakos ịvairioms mokslo sritims, bet ir ịkvépé ivvairius socialinius judëjimus Jungtinèse Amerikos Valstijose, Vokietijoje bei postsocialistineje Lietuvoje.

Reikšminiai žodžiai: Gimbutas (Gimbutienè), Lietuva, figūrèlès, tatuiruotès, kūno puošyba, protèviai, feminizmas. 


\section{GIMBUTAS VISION, THE ARCHAEOLOGICAL SOURCES AND LANGUAGE OF THE GODDESS}

Marija Alseikaite Gimbutas was among the first archaeologists who took up the subject of a matristic prehistoric society in this extent. In fact, she turned to two intricate themes of prehistory combining them: gynocentrism and religion. This was brave as both were long neglected by research, the latter often seen upon as strange and 'different' by many archaeologists (Hansen 2003; Mattes 2008). 'If you say anything about the ritual side of the culture they will say you are cracked. You cannot say anything about the spiritual side of the culture' (Gimbutas 1992; Murdock 2014, 945). She was visionary when it comes to the classical Indo-European issue. Her Kurgan-hypothesis explained the origin of the IndoEuropeans by migratory actions, by incursions of mounted warriors originating from the steppes of the Caucasus decades before DNA analysis of prehistoric individuals from the cultures in question would strengthen and vindicate Gimbutas' solution (Haak et al. 2015). ${ }^{1}$

While Gimbutas early works, e.g. her $\mathrm{PhD}$ thesis 'Die Bestattung in Litauen in der vorgeschichtlichen Zeit', (1946) were well respected within the discipline, her later research was receipted very controversial. It opposed the contemporary positivist paradigm of New Archaeology.

Gimbutas melted diverse archaeological cultures, many different artefact types from a large canon of sites and different material cultures dating to various periods, often disregarding the archaeological context, find circumstances, and provenance, into one big culture. Instead she looked at the individual objects or their decoration, which she, by a rather free iconographic interpretation, identified as a medium for the 'Goddess' and as relics of this belief. In order to illustrate how justified and self-evident the general methodological criticism within archaeology is, a comprehensive outline on the variety of the archaeological material Gimbutas dealt with, is presented in table 1.

'Old Europe' is the terminus Gimbutas chose for this huge realm. She created a vision of a peaceful prehistoric land, home to a gynocentric organised agricultural society where women lived free, self governed and pacific, worshipping the central 'Goddess' religion (2001a). Gimbutas considered this area as 'Prepatriarchal Europe' (2001b, 1). She uses the term of the 'Old European matrilineal system' (2001b, 121), not 'matriarchy'2 to mark the societal governing and importance of women

\footnotetext{
${ }^{1}$ Here Furholt must be mentioned, who argues for a more careful application of a DNA-Data (Furholt 2018, 159).

2 The terms 1) matrilineality, respectively 2) matriarchy respectively gynecocracy basically mean 1) the tracing of kinship to the female line. It may correlate with a social system in which each person is identified with their mother's lineage which can include inheritance of property and/ or title. 2) female-ruled societies. Further related terms are 3) matrilocality which describes the custom of couples residing with or near the women's parents. Thus, the female offspring of a mother remain living in (or near) the mother's house, thereby forming clan-families, typically consisting of three or four generations living together. The term matrifocal 4) determines a social structure where mothers head families and fathers play a less important role in the home and in bringing up children. Examples from anthropology, ethnography and history give proof of these forms of social organization in Africa, (native) America, East Asia and South East Asia and Europe. Nevertheless, these terms are debated by individual scholars as well as in different research disciplines (e.g. anthropology, history, modern matriarchal studies, feminist studies, sociology etc. as to their various degree of (execution of) female power or female ruler ship and sometimes the egalitarian degree of the respective society. To many, matriarchy means a society which s government and power is in the hands of women while to others it is a society in which women's power is equal or superior to men (Eller 2006, 12), respectively a society "where women and men share equally in production and power (Adler 2006, 194). This extensive issue of terminology represents a subject of its own and thus cannot be discussed further in this place.
} 


\begin{tabular}{|c|c|c|c|c|c|c|c|c|c|c|c|c|c|c|c|c|c|c|c|c|c|c|c|c|c|}
\hline 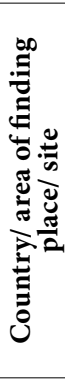 & $\mid$ & : & 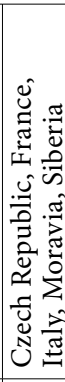 & \begin{tabular}{|c|} 
\\
$\frac{\pi}{\pi}$ \\
$\frac{\pi}{5}$ \\
$\frac{\pi}{5}$
\end{tabular} & 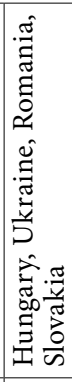 & 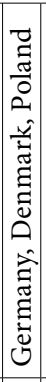 & 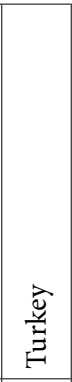 & 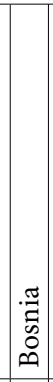 & 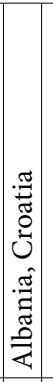 & 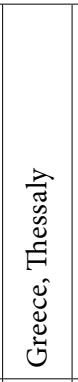 & 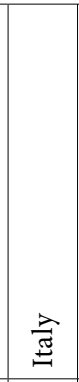 & 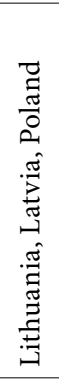 & 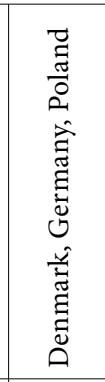 & 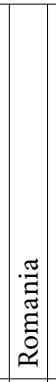 & 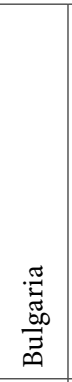 & 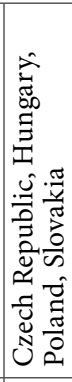 & 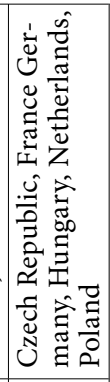 & 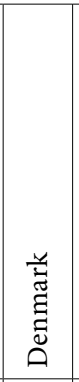 & 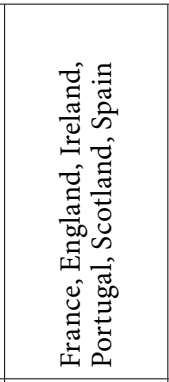 & & 悉 & 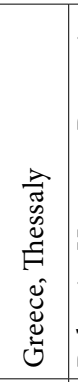 & 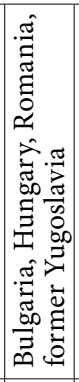 & 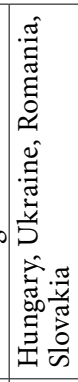 & \\
\hline 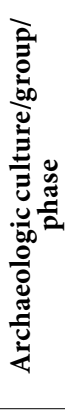 & 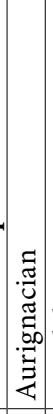 & 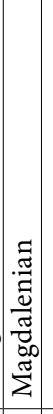 & 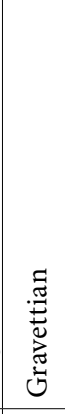 & 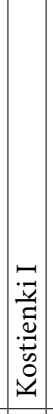 & 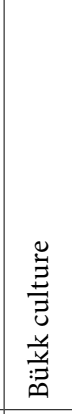 & 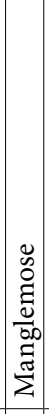 & 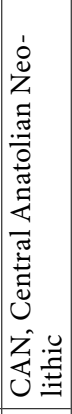 & & 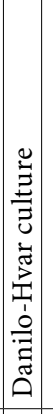 & 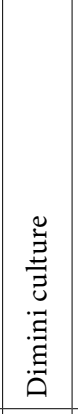 & 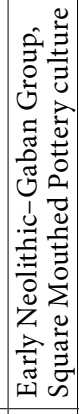 & 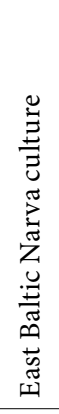 & 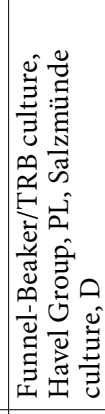 & 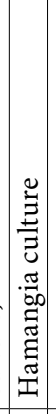 & 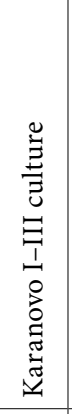 & 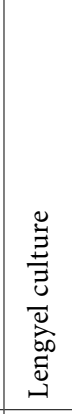 & 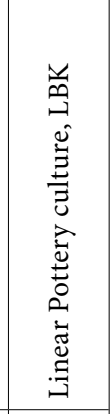 & 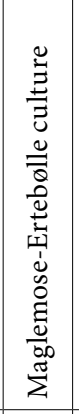 & 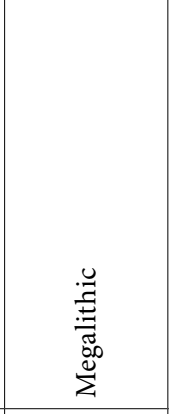 & & 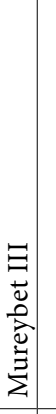 & 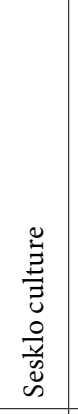 & 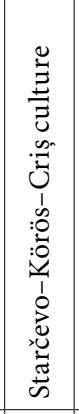 & 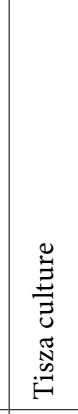 & $\underline{\underline{z}}$ \\
\hline 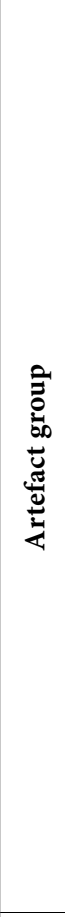 & 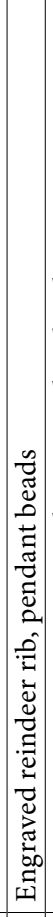 & 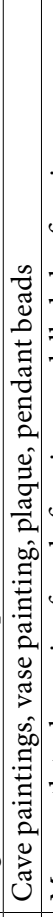 & 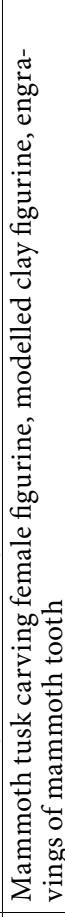 & 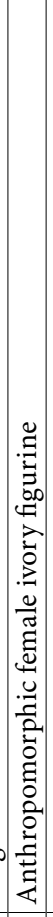 & 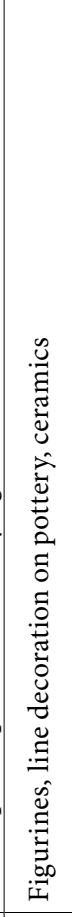 & 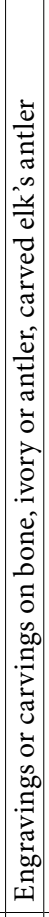 & 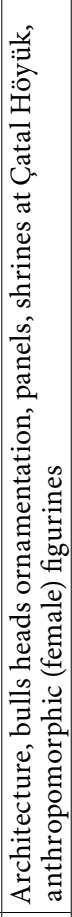 & 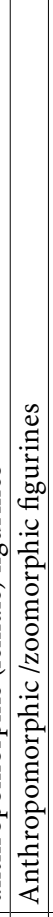 & 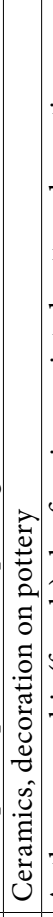 & 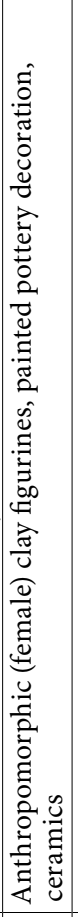 & 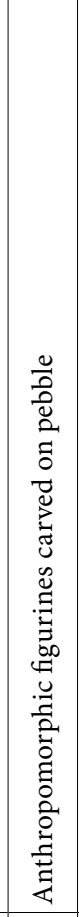 & 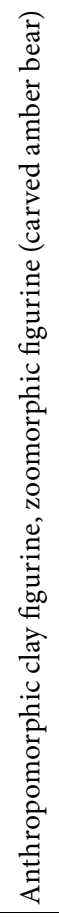 & 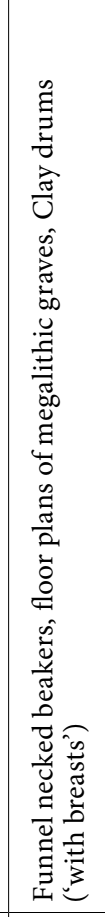 & . & 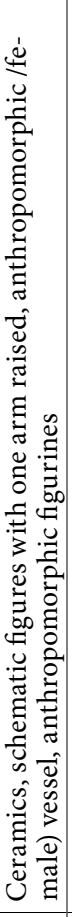 & 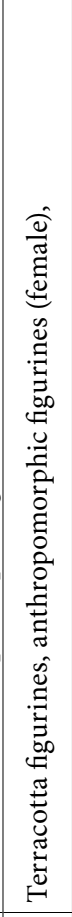 & 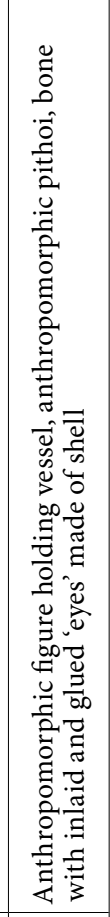 & 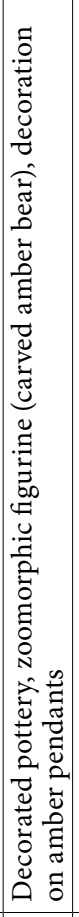 & 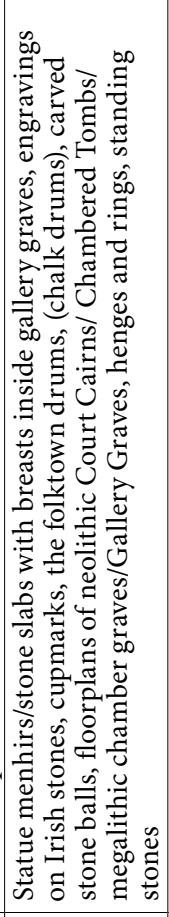 & 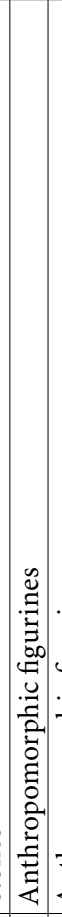 & 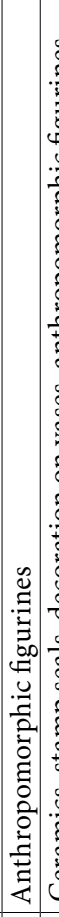 & 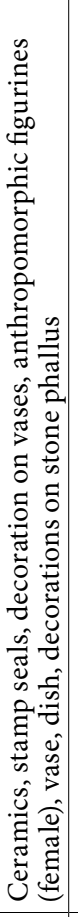 & 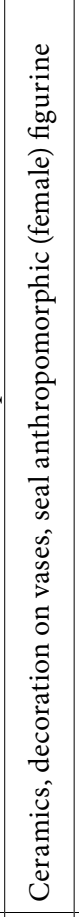 & 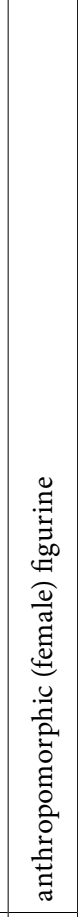 & 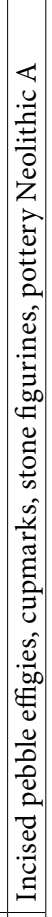 \\
\hline $\begin{array}{l}\overrightarrow{0} \\
\stackrel{0}{0} \\
0\end{array}$ & 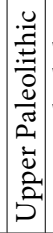 & 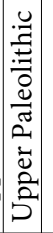 & 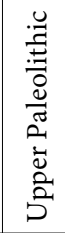 & 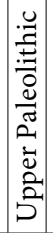 & 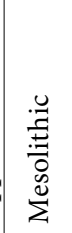 & $=$ & 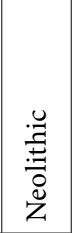 & & & $\begin{array}{l}\vec{z} \\
\overline{0} \\
\dot{0} \\
z\end{array}$ & 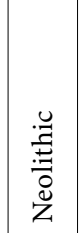 & 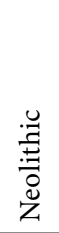 & $\begin{array}{l}\bar{D} \\
\text { 总 } \\
\text { Z }\end{array}$ & 蕜 & $\begin{array}{l}\text { 号 } \\
\text { : } \\
\text { z̆ }\end{array}$ & : & $\begin{array}{l}\bar{\Xi} \\
\text { ¿ } \\
z\end{array}$ & 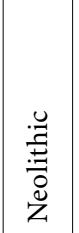 & : & & 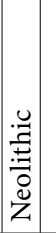 & $\begin{array}{l}\text { : } \\
\text { ठ̀ } \\
z\end{array}$ & 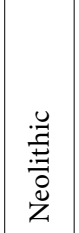 & 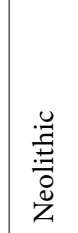 & \\
\hline
\end{tabular}

Table 1. The artefact groups and their respective archaeological culture classification and country of origin/ site/ finding location Gimbutas used to construct Old Europe are listed in chronological order

1 lentelè. Archeologinių dirbinių grupès ir klasifikacija pagal kultūras, kilmès šalį / archeologinę vietovę / radimvietę, išdèstytos chronologine tvarka, pagal kurias M. Gimbutienè apibrèžè Senąją Europą 
but coevally to express men were not suppressed. According to her books, the time frame for its cultural existence is between 7000-3500 BC. In Gimbutas' opinion, the end of this society was brought by aggressive patriarchal nomadic Kurgan-people, originating from the wide Eastern Steppe, riding several invasions into matriarchal Old Europe, between 4300 and 2900 вс $(2001 b, 131)$ and finally destroyed its social structure.

Despite all the justified criticism on material and method, Gimbutas was, in contradiction to the majority of matriarchy researchers, among the first to deliver a cultural, geographic and chronological frame including a hypothesis for the decline of a women governed society.

To Gimbutas ' (...) there is no other religion. There is the goddess religion as far as we go back. Of course, we can go back only when the earth monuments begin for instance the cave art and sculptures and all that but also in even earlier times in mysterion and lower Paleolithic (...). There is no father image at all; no male images and sculptures just the goddesses' (Goode 1986, 01:33-02:25). Thus she formulates an unrealistic historical claim to absoluteness here. She based this religion majorly on the finds of figurines, repeating elements such as decorations and patterns from various find categories and 'deciphered the artefacts', not explaining why these represent the Goddess but presenting them as self evident. The pure shape of an object, e. g. a ceramic vessel, (Fig. 1:1-5) represents a symbol, e. g. for the uterus or the vulva (Gimbutas 2001a, 20, Fig. 30) or the sheer decoration, e. g. bi-lines (Fig. 2:15) streamed lines (Fig. 2:7) and chevrons (Fig. 2:14) are associated with the Goddess. The single components are focusing on the feminine, fertility, pregnancy, also death and regeneration. Gimbutas joint these individual symbols together alike words to construct a sentence, in order to express a metalanguage which she invented and called 'the Language of the Goddess' (2001a). The Old European pantheon is dominated by the mother, the supreme creator and is grouped into the Bird Goddess (Fig. 1:4-5; Fig. 3:1-3, 7-8,), the Birth-Giving Anthropomorphic Goddess (Fig. 3:6), the Nurse or Mother holding a child, the Snake Goddess (Fig. 3:5), the Bear Goddess (Fig. 2:1, 5), the deer (Fig. 2:6, 16) and the elk-doe (Fig. 2:13). Additionally the Goddess makes an appearances as Triangle and Hourglass, the Stiff Nude as Death, the Toad/Frog Goddess, the Hedgehock Goddess, the Fish Goddess, Bee and Butterfly Goddess, the Pregnant Goddess. The vulture, the Bird of Prey Goddess, the Owl Goddess (Fig. 1:2-3, 5; Fig. 3:10) represent the Goddess of Death and Rebirth, death or 'the magician Goddess of Regeneration' (Gimbutas 2001a, 207).

The male divinity is represented by the Master of Animals: Male God holding Hook, Daimon of Fertility and Regeneration, the God of Annual Renewal: Youthful and Sorrowful (Gimbutas 2001b, 326). There are only two male symbols incorporated into Gimbutas' language code: the centaur, or bull (Fig. 2:9-10, 12) man, representing stimulating live energy and the (horned/masked) ityphallic male figure (Fig. 2:2) which represents the stimulator of rising life energy (2001a, 322). The latter is also typified by depictions of goats (Fig. 2:3-4) or rams (Fig. 2:8-11). The same is applies for the figurines. The male are clearly underrepresented in Gimbutas gynocentric vision and this does not correlate with the material. She applied a selective treatment of the material. This is highly problematic as the male ones are practically ignored. There are male images among the Upper Paleolithic anthropomorphic figurines and in fact, no source can affirm that more than fifty percent of the imagery is recognizably female' (Tringham, Conkey 1998, 27). Meskell rightly criticizes that Gimbutas sometimes even interpreted the clearly male as female (Meskell 1995, 80).

The Hypothesis of Old Europes Religion majorly bases on figurines, on the South East European material in specific. Gimbutas excavated more than 

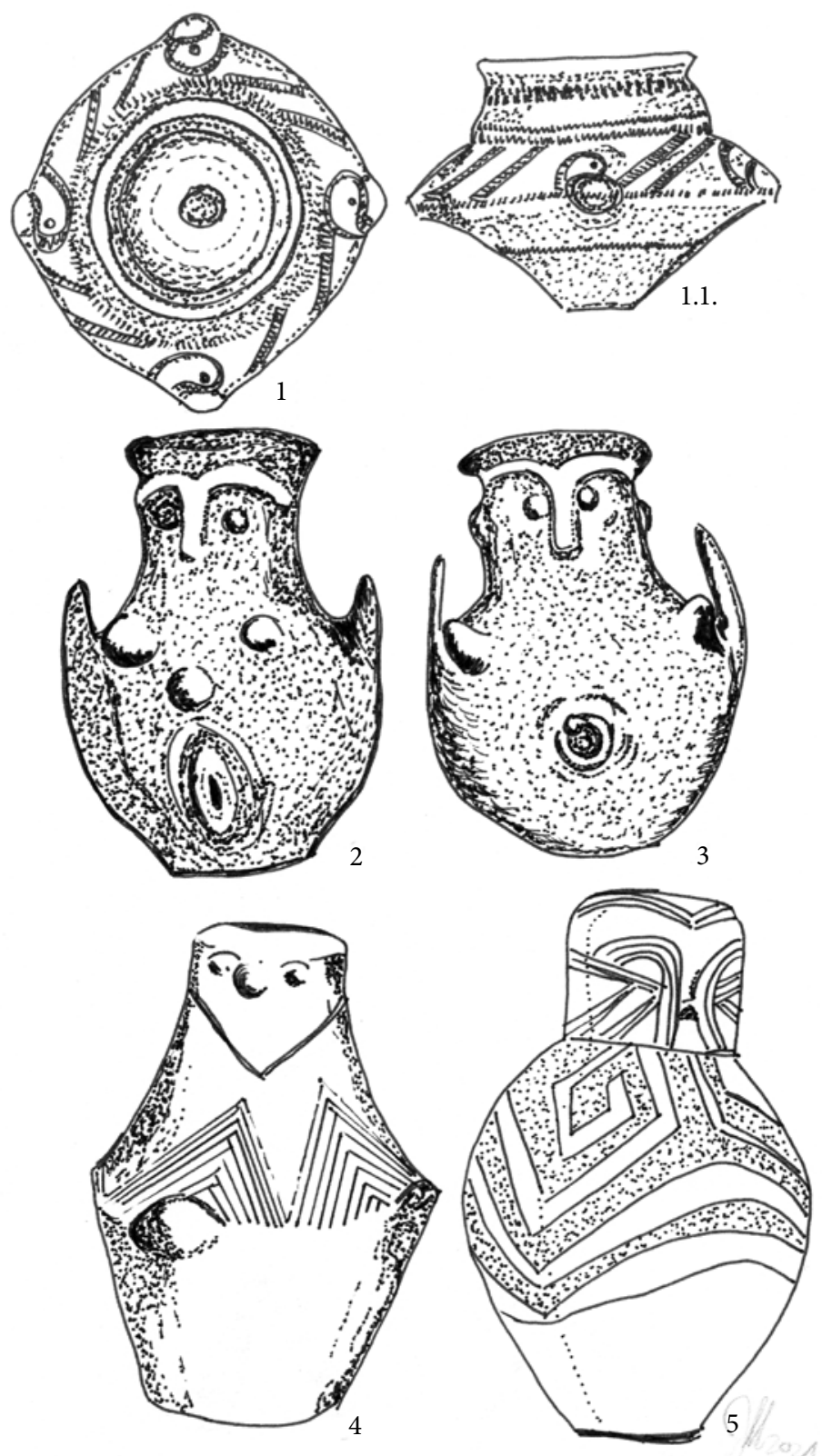

Fig. 1. Ceramic vessels representing several forms of the Goddess (after Gimbutas 2001a; 2001b): 1 - Spirals, graphite painted, H. $8.8 \mathrm{~cm}$, Karanovo VI, Tangiru, near Bucharest, Romania; 2 - Burial urn with emphasized vulva and serpentine umbilical cord, H. $24.3 \mathrm{~cm}$, Aegean/W Anatolian Early Bronze Age, Poliochni, town on Lemnos, 3000-2500 BC; 3 - Burial urn with serpentine umbilical cord, H. 23.1 cm, Troy II-III, 3000-2500 BC; 4 - Nippled vase, H. 23.2 cm, Early Vinča, Radacje, near Niš, Serbia and Montenegro; 5 - Lidded jar, decoration with abstracted yes, Vinča culture, H. $58.3 \mathrm{~cm}$, no place \& no date given. Drawings by Julia Mattes.

1 pav. Skirtingų formų molio dirbiniai, vaizduojantys Deivę (pagal Gimbutas 2001a; 2001b): 1 - spiralè, nuspalvinta grafitu (aukštis - 8,8 cm). Karanovo VI, Tangiru, Rumunija; 2 - laidojimo urna, dekoruota išryškinta vulva ir išsiraičiusia virkštele (aukštis 24,3 cm). Egèjo / Vakarų Anatolijos ankstyvasis bronzos amžius Poliochni, Graikija, 3000-2500 m. pr. Kr.; 3 - laidojimo urna su virkštele (aukštis - 23,1 cm). Troja II-III, 3000-2500 m. pr. Kr.; 4 - vaza su speneliais (aukštis - 23,2 cm). Ankstyvoji Vinčos kultūra. Radaje šalia Nišo, Serbija ir Juodkalnija; 5 - indas su dangteliu, dekoruotas abstrakčiomis akytėmis (aukštis - 58,3 cm). Vinčos kultūra. Radimvietè ir datavimas nepateikti. Julia Mattes pieš. 


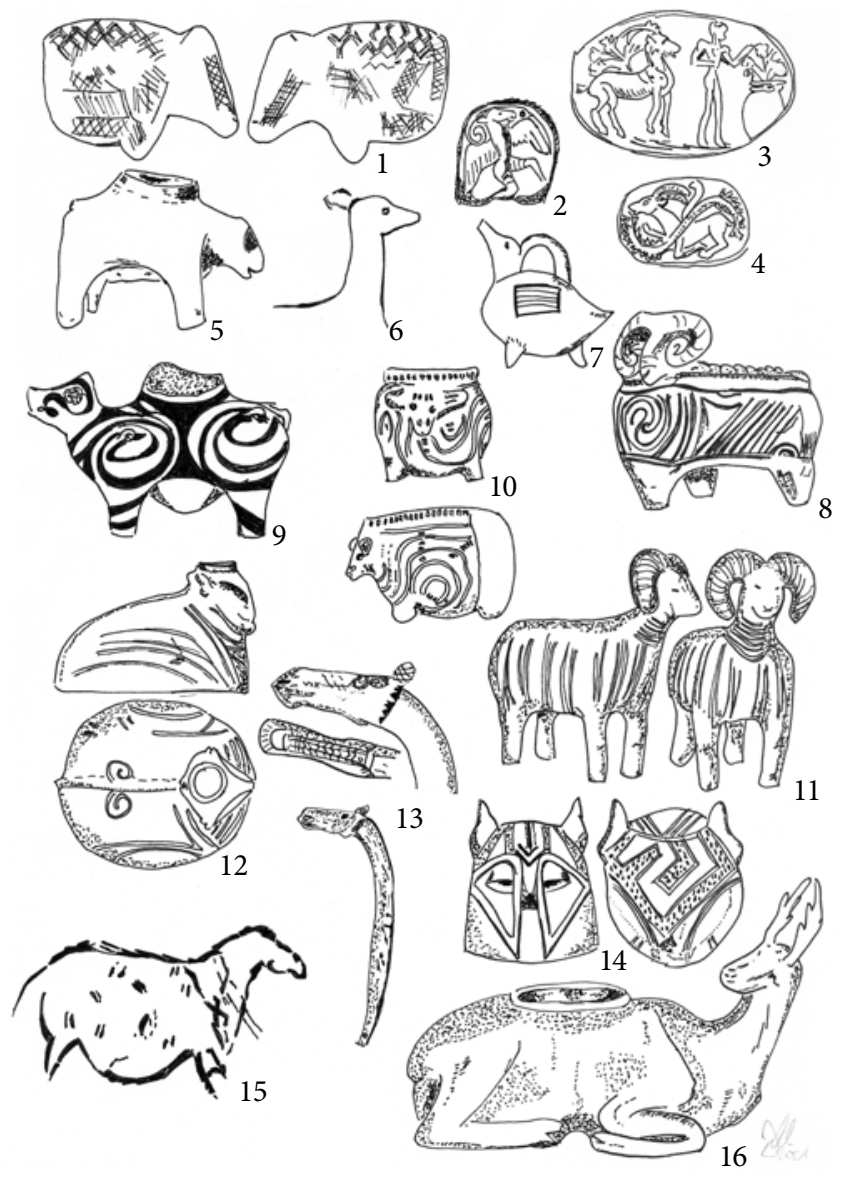

500 female figurines. 'I have seen in the museums all over Europe thousands and thousands of them in storage rooms ... lying there, not understood at all. In all the publications I knew, I never found any answer. What are these sculptures?' (Gimbutas interview; Marler 1996, 44). The extensive work evolved from a duration of over three decades. 'In the beginning I couldn't see anything. Luckily, I started deciphering, and from very tiny shards I began to piece it together. I had to make my own way, little by little' (Gimbutas, interview 1968, Marler 1996, 45). She states additionally: 'Some twenty years ago when I first started to question the meaning of the signs and design patterns that appeared repeatedly on the cult objects and painted pottery of Neolithic Europe, they struck me as being pieces of a gigantic
Fig. 2 . Zoomorphic artifacts representing the Old European Pantheon (after Gimbutas 2001a; 2001b): 1 - Amber bear, H. $17.1 \mathrm{~cm}$, Maglemose culture, Resen, Jutland, Denmark; 2 - Ram-Bird hybrid winged man on seal, H. $2.5 \mathrm{~cm}$, Minoan, Kato Zakros, Crete, Greece; 3 - Goat, man and sprouts engraved in a gold ring, diam. $3 \mathrm{~cm}$, Mycenae, 16th century bc; 4 - Goat, seal, ca. $4 \mathrm{~cm}$, Minoan I-II culture, Phaistos, Crete, Greece; 5 - Bear shaped terracotta vase, H. $11 \mathrm{~cm}$, Cucuteni culture, Sipenitsi, Ukraine; 6 - Deer, engraved in a cave, Magdalenenian, Labastide, haute Pyrénées, France; 7 - Zoomorphic askos, H. $12.9 \mathrm{~cm}$, Anatolian early Bronze Age, Yortan, Turkey; 8 - Ram shaped container, H. $10.6 \mathrm{~cm}$, Karanovo, Jasa Tepe, Plovdiv, Bulgaria, 5000-4000 BC; 9 - Tauroformed terracotta lamp, H. 10.6 cm, Karanovo, Sitagroi III, Drama Plain, Greece; 10 - Small bull vase, H. $6.6 \mathrm{~cm}$, decorum may represent lunar phases, Linear Pottery, са. 5000 вс, Hienheim, Bavaria, Germany; 11 - Rams, terracotta figurines, $H .13 .5 \mathrm{~cm}$, Late Lengyel, Jordanów, Silesia, Poland; 12 - Bull vase, H. $11.1 \mathrm{~cm}$, Karanovo, Gumelnița, lower Danube, 4300 BC; 13 - Elk, carved cult staff, antler, H. $46 \mathrm{~cm}$, Narva culture, Šventoji, Lithuania; 14 - Lids. Left: Early Vinča culture, H. 14 cm, Vinča. Right: Mid-Vinča culture, H. $12.4 \mathrm{~cm}$, Vinča; 15 - Wild-horse mare, cave-painting ca. $50 \mathrm{~cm}$, La Pileta, near Gibraltar, Spain; 16 - Deer shaped cult vase, H. $15.6 \mathrm{~cm}$, Hacilar VI, Central Anatolian Neolithic, Turkey. Drawings by Julia Mattes.

2 pav. Zoomorfiniai dirbiniai, vaizduojantys Senosios Europos dievų panteoną (pagal Gimbutas 2001a; 2001b): 1 - gintarinè meška (aukštis - 17,1 cm). Maglemozès kultūra. Rèzenas, Danija; 2 - avino-paukščio sparnuoto žmogaus hibridas ant antspaudo (aukštis - 2,5 cm). Mino kultūra. Kato Zakros, Kreta, Graikija; 3 - ožka, vyras ir augalai ant auksinio žiedo (skersmuo - $3 \mathrm{~cm}$ ). Mikènai, Graikija, 16 a pr. Kr.; 4 - ožka, antspaudas (apie $4 \mathrm{~cm}$ ). Mino I-II kultūra. Faistos, Kreta, Graikija; 5 - meškos formos terakotos indas (aukštis - $11 \mathrm{~cm}$ ). Kukutenio kultūra. Sipenitsi, Ukraina; 6 - elnias, išraižytas urve. Madleno kultūra. Labastide, Aukštutiniai Pirènai, Prancūzija; 7 - zoomorfinès formos indas (aukštis $-12,9 \mathrm{~cm}$ ). Anatolijos ankstyvasis bronzos amžius, Jortanas, Turkija; 8 - avino formos indas (aukštis - 10,6 cm). Karanovo kultūra. Jasa Tepe, Plovdivas, Bulgarija, 5000-4000 m. pr. Kr.; 9 - jaučio formos terakotos lempa (aukštis - 10,6 cm). Karanovo kultūra. Sitagroi III, Drama lyguma, Graikija; 10 maža buliaus formos vazelè, puošyba galimai vaizduoja Mènulio fazes (aukštis $-6,6 \mathrm{~cm}$ ). Juostinès keramikos kultūra, apie 5000 m. pr. Kr., Hienheimas, Bavarija, Vokietija; 11 - Terakotos avinèliai (aukštis $-13,5 \mathrm{~cm}$ ). Vèlyvoji Lendjelio kultūra. Jordanuv, Silezija, Lenkija; 12 - jaučio formos indas (aukštis - 11, $1 \mathrm{~cm}$ ). Karanovo kultūra, $4300 \mathrm{~m}$. pr. Kr. Gumelnica, Žemutinis Dunojus, Rumunija; 13 - apeiginè lazda briedžio galva (aukštis - $46 \mathrm{~cm}$; ragas). Šventoji, Lietuva; 14 - dangteliai. Kairèje: ankstyvoji Vinčos kultūra. Vinča (aukštis $-14 \mathrm{~cm}$ ). Dešinejje: vidurinè Vinčos kultūra. Vinča (aukštis - 12,4 cm); 15 - laukinẻ kumelè, piešinys urve (apie $50 \mathrm{~cm}$ ). La Pileta, šalia Gibraltaro, Ispanija; 16 - apeiginis elnio formos indas (aukštis - 15,6 cm). Hacilar VI, centrinès Anatolijos neolitas, Turkija. Julia Mattes pieš. 


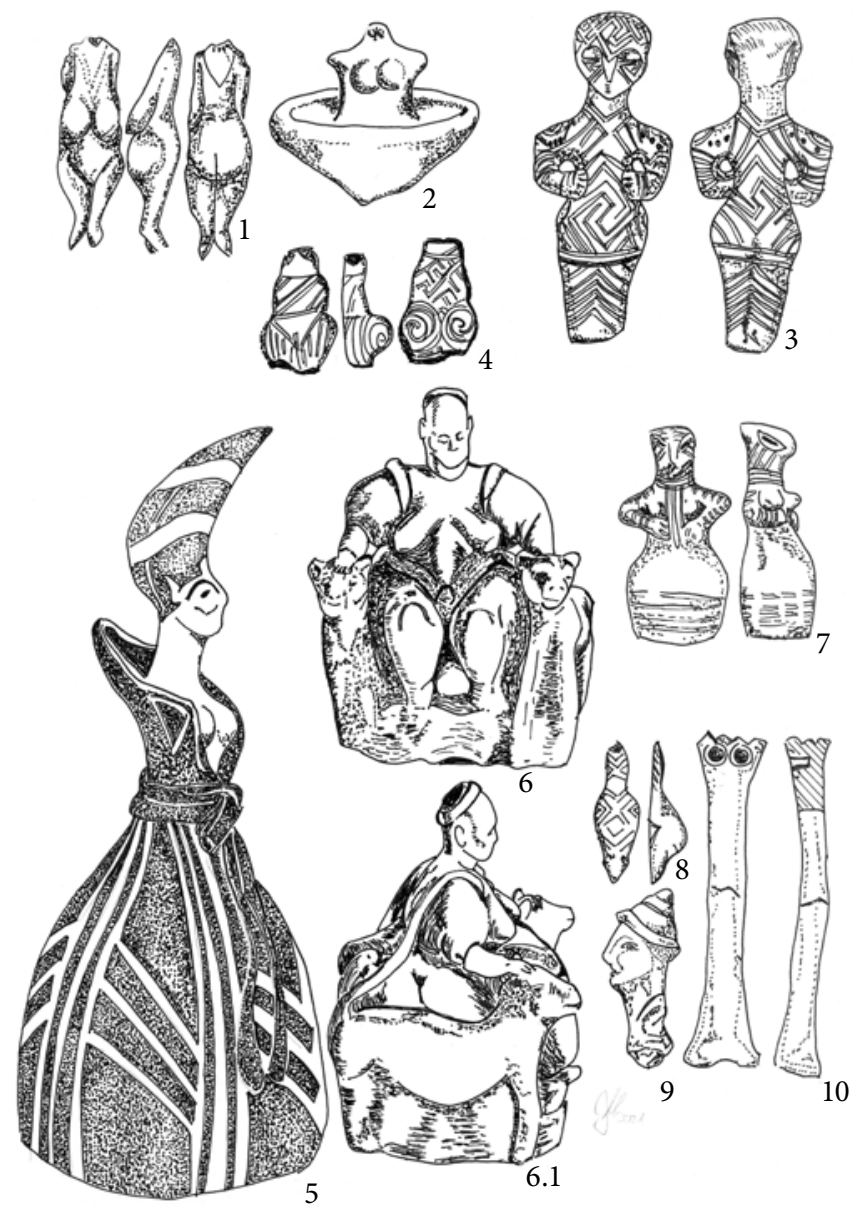

Fig. 3. Anthropomorphic figurines representing several Goddesses (after Gimbutas 2001a; 2001b): 1 - Upper Paleolithic, ivory figurine, H. $15.5 \mathrm{~cm}$, Kostienki I, River Desna, Ukraine, ca. 20000 BC; 2 - beaked figurine rising from the center of a dish, H. $9.1 \mathrm{~cm}$, Karanovo VI/Gumelnița, Ciolaneşti, Romania, 4500-4300 вC; 3 - late Neolithic, figurine with meander decorum, H. $8.6 \mathrm{~cm}$, Vinča culture, Potporanj, near Vršac, Serbia, ca. 4500 вс; 4 - figurine decorated with whorls and circles, H. $5.56 \mathrm{~cm}$, Karanovo IV, Kalojanovec, near Nova Zagora, Bulgaria, ca. 5200-5000 BC; 5 - Bronze Age, figurine, H. $16.3 \mathrm{~cm}$. Middle Minoan I, Petsofas hill sanctuary, Crete, Greece, ca. 2100-1800 BC; 6 - enthroned female figurine giving birth, flanked by felines, $\mathrm{H}$. $11.8 \mathrm{~cm}$, Central Anatolian Neolithic, Çatal Höyük, Level II shrine, Turkey, ca. 6000 BC; 7 - Neolithic, figurine with breasts, H. $8.6 \mathrm{~cm}$, Dimini culture, Tsangli phase, Zarkou at Larisa, Thessaly, early 5th mill. BC; 8 - Upper Paleolithic, ivory figurine, ca. H. $7 \mathrm{~cm}, \mathrm{Mezin}, \mathrm{Desna}$ valley, Ukraine, ca. 18 000-15 000 BC; 9 - Chalcolithic, figurine wearing a hat, Vinča culture, near Belgrade, Serbia, ca. 5000 вC; 10 - Neolithic, cow bone with inlaid shell eyes, H. 11.5 cm, LBK, Ensisheim, Upper Rhine, France, ca. 5000 BC. Drawings by Julia Mattes. 3 pav. Antropomorfinès figūrèlès, vaizduojančios ịvairias deives (pagal Gimbutas 2001a; 2001b): 1 - kaulinė figūrèlè (aukštis $15,5 \mathrm{~cm}$ ). Vèlyvasis paleolitas, apie 20000 m. pr. Kr. Kostienki I, Desnos upè, Ukraina; 2 - figūrèlè su snapu, stovinti centrinėje indo dalyje (aukštis - 9,1 cm), 4500-4300 m. pr. Kr. Karanovo IV/Gumelnica, Ciolanešti, Rumunija; 3 - figūrèlè su vingiuojančiu ornamentu (aukštis - 8,6 cm). Vèlyvasis neolitas, apie 4500 m. pr. Kr. Vinčos kultūra, Potporanj prie Vršaco, Serbija; 4 - figūrèlè, dekoruota apskritimais ir sūkurèliais (aukštis - 5,56 cm). Apie 5200-5000 m. pr. Kr. Karanovo IV, Kalojanovec prie Nova Zagoros, Bulgarija; 5 - figūrèlè (16,3 cm). Bronzos amžius, apie 2100-1800 m. pr. Kr. Vidurinè Mino kultūra I. Šventykla ant Petsofo kalvos, Kreta, Graikija; 6 - figūrèlè, vaizduojanti gimdančią moterị, kuri sẻdi soste, apsupta kačių (aukštis - 11, 8 cm), apie 6000 m. pr. Kr. Centrinès Anatolijos neolito laikotarpis. Čatal Hiujukas, šventykla kultūriniame sluoksnyje II, Turkija; 7 - figūrèlè su krūtimis (aukštis - 8,6 cm). Neolito laikotarpis, V tūkstantm. pr. Kr. pradžia Dimini kultūra, Tsangli fazè. Zarkou, Tesalija, Graikija; 8 kaulinè vèlyvojo paleolito figūrèlè (aukštis - apie $7 \mathrm{~cm}$ ), apie 18000-15000 m. pr. Kr. Mezin, Desnos slènis, Ukraina; 9 - kepurèta figūrèlè. Eneolito laikotarpis, apie 5000 m. pr. Kr. Vinčos kultūra. Šalia Belgrado, Serbija; 10 - karvès kaulas su inkrustuotomis kriauklių akytėmis (aukštis - 11,5 cm). Neolitas, apie 5000 m. pr. Kr. Juostinės keramikos kultūra. Ensisheimas, Reino aukštupys, Prancūzija. Julia Mattes pieš. 
jigsawpussle - two thirds of which was missing. As I worked at its completion, the main themes of the Old European ideology emerged, primarily through analysis of the symbols and images and discovery of their intrinsic order. (...) They reveal the basic world-view of Old European (pre-Indo-European) culture. (...) This present work grows out of the vast body of symbols preserved in the artefacts themselves. My primary presupposition is that they can best be understood on their own planes of reference, grouped according to their inner coherence' (Gimbutas 2001a, $\mathrm{xv}$ ). Gimbutas view reveals an 'object agency' which even implies a somewhat animistic perspective on archaeological material. As Gimbutas perception is religious, her way of knowing and understanding of the world is strongly spiritual. This forms an intense contradistinction to recent western dualism, which demands a distant view for empirical research, resulting in a clear separation from material and spiritual, emotions and cognitions. Thus, to the author, the background for the wide rejection of Gimbutas opus within the discipline of archaeology lies not only in her methods and interpretations but is based on a much deeper rooted clash of these two opposing ontologies.

The research on prehistoric figurines was initiated during the last two decades of the 19th century, when according objects were recognized for the first time. Quite a few scholars consider Gimbutas work as an incentive for research on these genera. '(...) we argue that neolithic figurine studies were by and large developed as a response to her theory: although the discipline reacted with considerable annoyance at first (...)' (Kokkinidou, Nikolaidou 2014, 706).

Paleolithic, Neolithic and even some Bronze Age and Iron Age figurines are generally difficult to interpret and often tricky to clearly identify as anthropomorphic or zoomorphic. They can also be a hybrid mix of both or resembling none known species. Additionally their sex determination can often be equally intricate (Mattes 2019; 2020).
Hansen also addresses the difficult problem of the figurine interpretation in his fundamental contribution to the prehistory of Eurasia and concerned the chronology of figural art from the Palaeolithic. The calibration of radiometric dates has led to new approaches in absolute dating of the Neolithic, whereby gaps in the dates fot the time between the Palaeolithic art in Europe and that of the oldest early Neolithic in western Asia could be filled (2007).

Figurines 'have to be interpreted to have a meaning in any century. Since figurines have been and can be interpreted in many different ways, each interpretation is a clear indicator off where a writer stands both on the past and on feminism' (Tringham, Conkey 1998, 24). The following examples of figurines finds demonstrate the above mentioned in specific.

Generally, in research history, prehistoric female figurines, in archaeology and other subjects, have a long tradition of being interpreted in the context of fertility which seems problematic to the author as it is often, possibly due to lack of context, too generalized and applied uniformly without consideration to the single case. This also and especially applies to subjects and scholars outside the discipline who feel compelled to decipher the true meaning of figurines without having any archaeological expertise.

Thus, these artefacts are thitherto often connected to a plain androcentric interpretation, to put it mildly. In the best case they were considered Venuses but often described as primitive and ugly, such as 'horribly distorted female forms (...) with an abdominal tumor' (Evans 1959, 148), respectively referred to 'as an erotic object for the satisfaction of the prehistoric male' (Navickaite 2019, 129). Tringham and Conkey criticize 'The ways in which these figurines have consistently been described by a wide range of academic scholars and others reflect the primacy of the notion of 'Women' as both an erotic and aesthetic ideal, and contemporary pornographic 
views of the female body as sexual object' $(1998,25)$. Regarding the research history of the figurines a second, so to speak other faction is to be observed: the interpretation of fertility and divinity. One of its most prominent representatives is the great Goddess, introduced by Gimbutas (Kaika 2018, 12). Whatever the individual interpretations of the female figures, they do prove, the feminine as such was important enough to be depicted, but it is too diverse to be generally reduced to fertility and pregnancy.

Watson and Gaydarska also criticize that most archaeologists interpret the majority of figurines connected to fertility $(2014,1)$. Sometimes interpretations of this kind, have a small, different twist to it but still focus on reproductiveness in the basis: Vierzig brang forth that it is not the individual fertility that is celebrated via Neolithic depictions of women but the power of reproduction in the sense of cyclic regeneration and cosmic rebirth and cosmic renewal $(2009,50,87)$ which makes the woman an 'icon of regeneration' $(2009,88)$, hence an object to execute a higher purpose, a divine plan. Like Vierzig, Gimbutas, too, homogenizes the prehistoric material and belongs to the group of researchers who strongly focus on the fecundity theme, but credit must be given to her for finally introducing an appreciative view, free from objectification or aesthetic evaluations of the female body.

Bailey, in contradiction, to the aforementioned, acknowledged the heterogeneous character of the South East European material, especially for the north-east Bulgarian Chalcolithic. On the example of Golyamo Delchevo, he pursued a profane interpretation: a try to depict the individual inhabitants of the settlement (Bailey 1994). Biel executed a contextual analysis, on the example of Gradešnica-Krivodol culture complex and concluded, the Neolithic and Chalcolithic clay figurines of Southeastern European could be representations of 'acting human beings', manufactured by each household after certain rules, containing elaborate symbols belonging to a communication system (Biel 1996, 153). These approaches not only furnish an alternative to the repetitive stereotypical fertility theme but also remove the interpretation of the figures from an androcentric sexist objectifying meaning.

\section{INTERPRETATIONS OF THE NEOLITHIC SOUTH EAST EUROPEAN FIGURINES AND THE PODURI-DEALUL SET}

At several settlement sites in the Balkans sets of anthropomorphic figurines and furniture made of clay have been found. The sets from Poduri-Dealul Ghindaru and from Isaiia-Balta Popii were excavated in Moldavia in North East Romania. Each was found inside a vessel, consists of 21 miniature figurines depicted in a seated position, twelve larger and nine smaller, along with thirteen small chairs and are dated to the Pre-Cucuteni II period, 4900-4750 вС and the second named is Pre-Cucuteni III, dating to $4700-4500 \mathrm{BC}$.

The Poduri-Dealul set ${ }^{3}$ was, along with two miniature clay items, deposited in a vase, found in a building structure which was interpreted as sanctuary destructed by a fire. The ensemble of figurines possesses small heads, with one exception (Fig. 4, 5), no arms and hands, wide hips and thighs, the legs are depicted by incised lines and bare feet. There are fifteen figurines, the largest, are up to $8.6 \mathrm{~cm}$ tall. Ten of the large figures and six of the small figures are depicted with closed legs, while five large and one small figure were created with legs slightly apart. The heads and necks appear cylindrical in their basic shape, the faces are abstracted with incised, elliptical or round eyes. The mouths, some are depicted open, are also represented by a single incised line or a round

\footnotetext{
${ }^{3}$ Cf. picture 5-1, https://www.tf.uni-kiel.de/matwis/amat/iss/kap_a/illustr/ia_1_7.html
} 


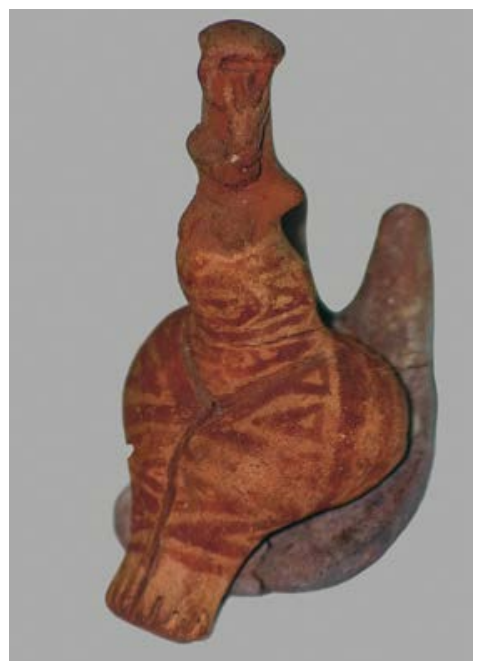

Fig. 4. 'Thinking' Cucuteni figurine of the Poduri-Dealul set with painting decoration. Moldavia in North East Romania. Photo by Cristian Chirita (available from: https://commons. wikimedia.org/wiki/File:CucuteniTatoo.jpg).

4 pav. Poduri-Dealul rinkinio „mąstanti“ Kukutenio kultūros figūrèlè, dekoruota piešiniais. Moldavija, šiaurès rytų Rumunija. Cristian Chirita nuotr. (prieiga per: https://commons.wikimedia. org/wiki/File:CucuteniTatoo.jpg).

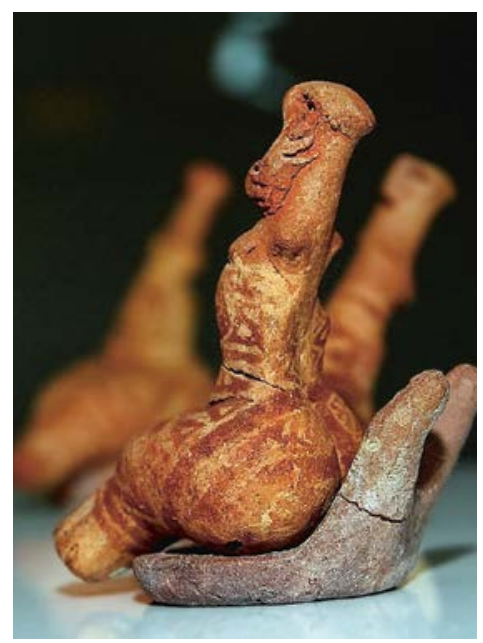

Fig. 5. 'Thinking' Cucuteni figurine of the Poduri-Dealul set, decorated with paint. Moldavia in North East Romania. Photo by Cristian Chirita (available from: https://commons.wikimedia. org/wiki/File:SoborulZeitelorCucuteni.JPG).

5 pav. Poduri-Dealul rinkinio „mąstanti“ Kukutenio kultūros figūrelè, dekoruota piešiniais. Moldavija, šiaurès rytų Rumunija. Cristian Chirita nuotr. (prieiga per: https://commons.wikimedia. org/wiki/File:SoborulZeitelorCucuteni.JPG). impression. Even if reduced to a minimum, they lend the figures different mimic expressions: some seem to be smiling or even laughing, others appear frowned or displeased.

Twelve of the large figurines are richly decorated with thick red painted lines, covering the part just above the ankles up to the torsi which otherwise seem naked. A single, slightly curved line around the neck is painted on one figurine, which could resemble a necklace or the hem of an unfinished tunic. The five small figures are only represented very hazily by the most necessary incised lines and are undecorated. The same applies to three of the large figures. At least one of them is so different in style that it could have come from another manufacturer. Perhaps it was added to the ensemble to increase the number of pieces in the collection or to replace a broken figure.

The figurines are often considered to be Goddesses but to the author the sex determination is not explicit. Ten of the figures appear to have small, round or at least suggested breasts. Primary male sexual characteristics are absent. In analogy to the Dumeşti set (ca. 4200-4050 вC), it could be argued that separated legs are a stylistic masculine element: six of in total twelve red clay Cucuteni figurines have plastically modelled legs depicted apart and three of these figurines show a schematic phallus made by an elevation of clay. The other six torsi with closed legs remind of female bodies, due to the rounded hips and legs and the general shape but here, breasts are absent. Eight of the figurines, five of the 'male' and three of the 'female' show molded nipples". The sex determination seems more clear for the Dumeşti set because the figurines appear much more like realistic depictions of human bodies. In contradiction, the author finds it difficult to state with certainty whether the Poduri creations are female or male representations or even of a different sex or gender or if they could even be sexless/genderless beings. Due

\footnotetext{
${ }^{4}$ Cf. picture 5-4a, https://www.tf.uni-kiel.de/matwis/amat/iss/kap_a/illustr/ia_1_7.html
} 
to the stylistics, the exaggerated proportions and the schematic, but not lifelike way in which they are presented, they seem humanoid but not really like actual human images.

The excavators interpret this set as religious PreCucuteni pantheon with a main goddess, representing a woman who is 'dignified, who has borne many children and whose appearance suggests a magic, ritual function' (Mantu, Dumitroaia 1997; Bailey 2010, 114).

To Gimbutas it represents snake goddesses, probably ready to be placed on an altar used for the reenactment of rites (2001a, 4, plate 9). The interpretation stems from the decoration of the figurines: 'antithetic snakes coiling over the abdomen, dotted triangles and lozenges over the ample thighs and legs, and cartouches over the buttocks' (ibid.).

Bailey described the Poduri set as 'one of the world's most extraordinary assemblages of prehistoric artefacts' $(2010,113)$ and argues 'there is no scientific support for the assumption that Neolithic and Copper Age religion was centred on cults of agricultural fertility' (Bailey 2010, 122). The author agrees with Bailey that the interpretation of the figurines is difficult, especially as due to a wide absence of burials in Cucuteni tradition, little is known about funerary rites.

Bailey assumes the figurines were objects of every day use '(...) handled, played with, worshiped, or cursed in their daily existence. From this perspective, it does not matter precisely how each figure (or an entire set) was used. Rather, the function of these objects is to be found at a deeper level of reality, upon which the community constructed and maintained a sense of who one was, what one should look like, and how one was distinct from others' (Bailey 2010, 124).

Watson and Gaydarska repeat this thought of every day use but opine a different interpretation. '(...) anthropomorphic figurines were powerful beings (...) in everyday routine or in special ceremonies, figurines were part of the making of current events. They had diverse roles and, in the cases discussed above, they are seen as empowering women to take the destiny in their own hands and to break the deadlock of infertility' (Watson, Gaydarska 2014, 8). They introduce the interesting hypothesis that the Poduri-Dealul and related sets would be 'infertility aid-kits' (ibid., 1). Hence they turn the frequent fertility interpretation around and suggest an opposite meaning of the artefacts. In contradiction, Dumitrescu believes that the set of 21 to him clearly female, figurines was used as a fertility aid, representing a monthly female cycle of 21 days (Dumitrescu 2008, 47). Here, the author disagrees on four points: First, it can not be stated with certainty that the figurines resemble humans, respectively women. Second, the interpretation, again, focuses on (in)fertility. Third, the average female menstrual cycle which above mentioned hypothesis is based on, divided into the follicular phase, ovulation and the luteal phase, is typically equaling a lunar cycle by its duration of 28-days. Fourth, the endocrine system is very sensitive and therefore susceptible to change, e. g. in the case of suboptimal nutrition, stress or breastfeeding which can prevent a 'normal' menstrual cycle for weeks, months, or even years. Therefore breastfeeding children is a method of preventing unwanted pregnancy, a lactational amenorrhea method (LAM) in modern medical terms. Some women breastfeed their children until the age of eight years or longer in hope of a contraceptive effect. It is a traditional method of contraception among some indigenous populations which is, according to recent medical studies by Moroole et al. still pursued in parts of Africa today (2020). Considering this fact (and multiple other possible disrupting factors for an absolute regular female cycle), it is legitimate to question whether prehistoric women really had cycles of the kind suggested by Dumitrescu and even Watson and Gaydarska. Even supposing they had, were they really counting the individual days or was 
it a more general awareness of a 'certain time'? The author therefore disagrees with the interpretations stated above and finds them unlikely.

However the 'community thought' of the PoduriDealul set figurines seems appealing as the mere number of figurines creates the basis for a community. This is reinforced by the association with the seating furniture, since collective sitting down represents a social symbol for community in many times and cultures.

To the author an interpretation of the set as a symbolic ancestor assembly, or better ancestor council, is thinkable. The element seated position with the additional chairs could be interpreted as a meeting. It is imaginable that the set of figurines was put up by contemporaries when they wanted to contact their foregone, especially when they needed advice. Some figurines are created with open mouth, a feature that leads to the association of talking and communicating - within the group but also possibly with the spectator. The different facial expressions of the individual figures, pensive, astonished, happily, dissatisfied, can also be interpreted as statements of different opinions on a subject about which the group seems to be discussing.

Only one of the figurines is depicted with arms, the left hand touching the face (Fig. 4, 5). To Gimbutas, this is 'a ritual gesture' (2001a, 4) while to the author it is a general expression of thoughtfulness. Possibly this is the eldest and wisest, the 'thinker'/'thinkeress' or main listener who receives the concerns and matters of the contemporaries.

Unlike other Neolithic cultures, there is little archaeological evidence of ancestor worship among Cucuteni, apart from a few finds of human cranium or other skeletal parts placed under house structures, which could be a slight indication of ancestor worship. Such custom is recorded for Denmark and Sweden from the middle Neolithic until the Iron Age and beyond, where people buried their foregone under the house floor, respectively under the threshold of the door, in hope for an apotropaic effect - the progenitors should protect the house and its inhabitants from intruding evil (Carlie 2004, 223; Mattes 2008, 134; Hem Eriksen 2013, 187). Analogies can be found when consulting the discipline of Ethnology. Steadman et al. state a universality of ancestor worship (1996) which is not to be mistaken as a religion per sé but instead represents a world wide phenomenon of different beliefs and (cultic) practices embedded in a cosmological system. Ancestor veneration can furnish histories of origins, explain relationship structures and define group memberships. 'In the simplest terms, an ancestor is a deceased forebear, a member of one's lineage, clan, or house who is no longer among the living. In some societies, ancestors are vital, powerful entities in the daily lives of those who fear, venerate, and propitiate them. These ancestors represent a select subset of the deceased, those kin who, for various reasons, remain part of the collective consciousness of their descendants. Such ancestors may demand sacrifices, offerings, and libations, provide protection and good health, or bring illness, grief and disaster' (Hageman, Hill, 2016, 4).

Thus, the author concludes that the figurines could represent modelled depictions of ancestors, who could be positioned in a circle, forming an assembly and addressed by people in need of counsel. The various facial expressions can be seen as mirroring the individual character and the variety of good and evil responses the forbearers are able to utter.

The difference in size may symbolically point to the importance of the respective figurines. The bigger ones, maybe resembling the eldest, and thus the most honorable and maybe most wise, are equipped with chairs, marking their importance are larger in size while the smaller ones, are minor in rank.

It is also possible that the little anthropomorphic creations are representative figures of the contemporaries, small, as they are the youngest in the lineage, which were placed on the laps of 
the great ones, the ancestors, so that through this physical contact the answers to the posed questions, the wisdom and strength of the elder symbolically passed into the seekers of help and advice. This is a psychological course of action, which can be staged and performed by means of miniature figures instead of a life-size scenario. Multiple performances of ancestral cults, both by means of miniature objects and life-size cult equipment, for example entire houses specially for spirits and ancestors, are documented by ethnographic sources, e. g. for the pacific region and South East Asia (Mattes 2008, 104).

To some scholars, the decorations on the Cucuteni and other South East European figurines resemble clothing or magic symbols (Marinescu-Bîlcu 1981, 38). It is of cause possible, that the decorative lines and symbols represent clothes or in some cases broad hip belts, but it is also possible that some figurines, were occasionally wrapped in textiles like dressed dolls.

The way in which the decorations of the male figurines of the Dumeşti set are depicted is indeed reminiscent of a dress, with a thin layer of clay threedimensionaly applied to the torso of the figure and thus resting on the body, while the decorations on the female representations are carved into the body and do not seem to represent an extra, external layer. In this case, the male attire of the Dumeşti set resembles a sash worn on the left, respectively on the right shoulder, and a hip belt ${ }^{5}$.

If the decorations of the figurines should originally represent cloths, the author is convinced that this is an ideal or wishful conception of clothing, since the techniques necessary to tailor such refined garments with according body tight cut (e.g. shown on the Poduri set or the female figurines of Dumești) do, according to the findings of research of costume history, not exist before the European Middle Ages and stretchy textiles needed to create this effect without elaborate tailoring technique are an invention of modern times (Thiel 2019).

To others, the figurine decorations represent tattoos (Dumitrescu 1979, 87; Bailey 2013). Although we have no proof for this as neither 'inked' mummies nor tattoo equipment was found in a respective context, the interpretation is generally not impossible. A vast body of references from ethnology and archaeology prove that the art of tattooing was already invented in the time of the Cucuteni culture and practiced in different regions of the world.

Natural 'tatau' colours are based on soot and regional plants such as saffron, henna, indigo, the blue-black Jagua of unripe Genipa americana fruits, Solanaceae and others. The decoration on the PoduriDealul figurines is red, a colour that is known from a find of two 12,000-year-old bowls with red, respective black pigments and sharp stone tools, discovered in the French Grotte des Fées which might represent a set of tattoo equipment.

The earliest definitive proof for a prehistoric tattooed human is the ca. 5300 year old Ötztal mummy, found in the border Region of the Austrian/ Italian Alps. The man's body showed 61 ink marks, grouped in 19 clusters of 1-3 mm thick and 7-40 mm

\footnotetext{
${ }^{5}$ Cf. https://www.tf.uni-kiel.de/matwis/amat/iss/kap_a/illustr/ia_1_7.html. An analogy of decorated Neolithic anthropomorphic clay figures and finds of corresponding actual clothing can be found in the GRK culture from Sweden. The figurines are occasionally decorated with stick imprints in such a manner that reminds of attire with certain beaded patterns. In several graves of the TRB, STR and GRK bone beads, tusk beads and bone plaques were found that were formerly stitched to cloths. A number of women's grave in three different cemeteries on Swedish Gotland contained about 100 seal teeth each, which were fastened to the dress until the knees, some of them applied in parallel rows (Stenberger 1943, 11; Janzon 1974). There are also shell beads positioned around the neck and the knees, probably formerly attached to the dress with the intention to make a rattling or rusting sound when the wearer moved (Malmer 2002, 83).
} 
black lines (Samadelli et al. 2015) which are probably the result of a medical treatment. ${ }^{6}$ The earliest examples of figurative tattoos were found on a female, respectively a male mummy from ancient Egypt, dated between 3351 and 3017 bc (Friedmann et al. 2018). Ancient tattooing was presumably most widely practiced among the Austronesian eccentricities whose early technologies developed before 1500 BC in Taiwan and coastal South China and later spread to the Indo-Pacific islands (Krutak, Deter-Wolf 2017).

Multiple finds of tattooing instruments were found during the early, middle and late Bronze Age in North Germany. So called tattoo pens (German: Tätowierstifte) are a common grave goods together with razor knives and tweezers deposited in urns of the Lüneburg Gruppe and among the usually rich body graves of the Sögel-Wohlde-Kreis. Less than ten centimetre small needles for tattooing are relatively frequent with the Stader Gruppe of the younger Bronze Age and in grave of the Lüneburger Gruppe, near Soltau-Fallingbostel (Probst 1996). Women's graves of the Early Bronze Age Adlerberg-Kultur, northern Upper Rhine in Rhineland-Palatinate, Hesse and in parts of northern Baden contain metal bodkins while men's graves were equipped with bone bodkins. Both are interpreted either as tools for leather crafting or for tattooing. Copper bodkins from Early Bronze Age graves of the Singen Gruppe in southern Germany are interpreted as tattooing needles as well (Probst 2011a; 2011b). For the Iron Age, intricate tattoos have been preserved through the mummified bodies of the Scythian cultures from the 6 th -3 rd century bc, e. g. among the Pazyryk culture. The 'Lady of the Ukok-Plateau' in the Altai mountains who might have been a healer or shaman (Molodin, 2005, 95-114; Molodin et al. 2007,
142). Her tattoos consist of intricate animal motives, of which two are placed on the right underarm, and seven are spread over the entire left arm from the wrist to the beginning of the shoulder. The images are considered to represent the membership a certain social class (Molodin et al. 2007, 143), hence they are creating identity.

In contrast to the aforementioned prehistoric and historic examples of tattoos which were placed on selected single parts of the bodies, the Poduri and Neolithic and Chalcolithic figurines of South Eastern Europe show 'whole body' modifications. If they were tattoos, they would be whole body tattoos, 'full body suit' in technical terms. Historic prove for such are earliest recorded for the 16th century on the Maquesas-Islands, the 17th century for the Southpacific region and for 18 th century Japan (van Dinter 2008, 40, 152; Cwojdzinski 2019, 57).

However, it is not known whether people in the time and region in question tattooed themselves, (maybe tattoo needles were, like the German Bronze Age examples made of organic material, such as bones and hence decomposed) and if so, whether they were able to apply such extensively large motives all over the body without causing serious health risks, such as probable bacterial infection. If they had the necessary knowledge of herbs and medicinal plants to prevent possible sepsis, which is likely to occur if the skin is broken during the process, especially in a non-sterile environment, the idea that the decoration on the figurines could resemble tattoos seems legitimate. Presuming tattooing of this kind did exist, some figurines (Fig. 6), e. g. the Cucuteni, clay figurine, from Novye Ruseshty I, Moldova (Fig. 6:4), the Late Neolithic, figurine with meander decorum, Vinča culture, Potporanj, near Vršac, Serbia and

\footnotetext{
${ }^{6}$ The mummified man showed signs of rheumatism and since the tattoos contain charcoal particles and are located on the joints, and the majority of them correspond to the acupuncture points known today, it can be assumed that they were applied to relieve pain. Presumably, the skin was scratched and medicinal herbs were placed in the wounds, which were then burnt with the tip of a hot instrument. Similar procedures have been practiced for centuries by the North African Berbers and in traditional Chinese medicine (van Dinter 2008, 25-26).
} 

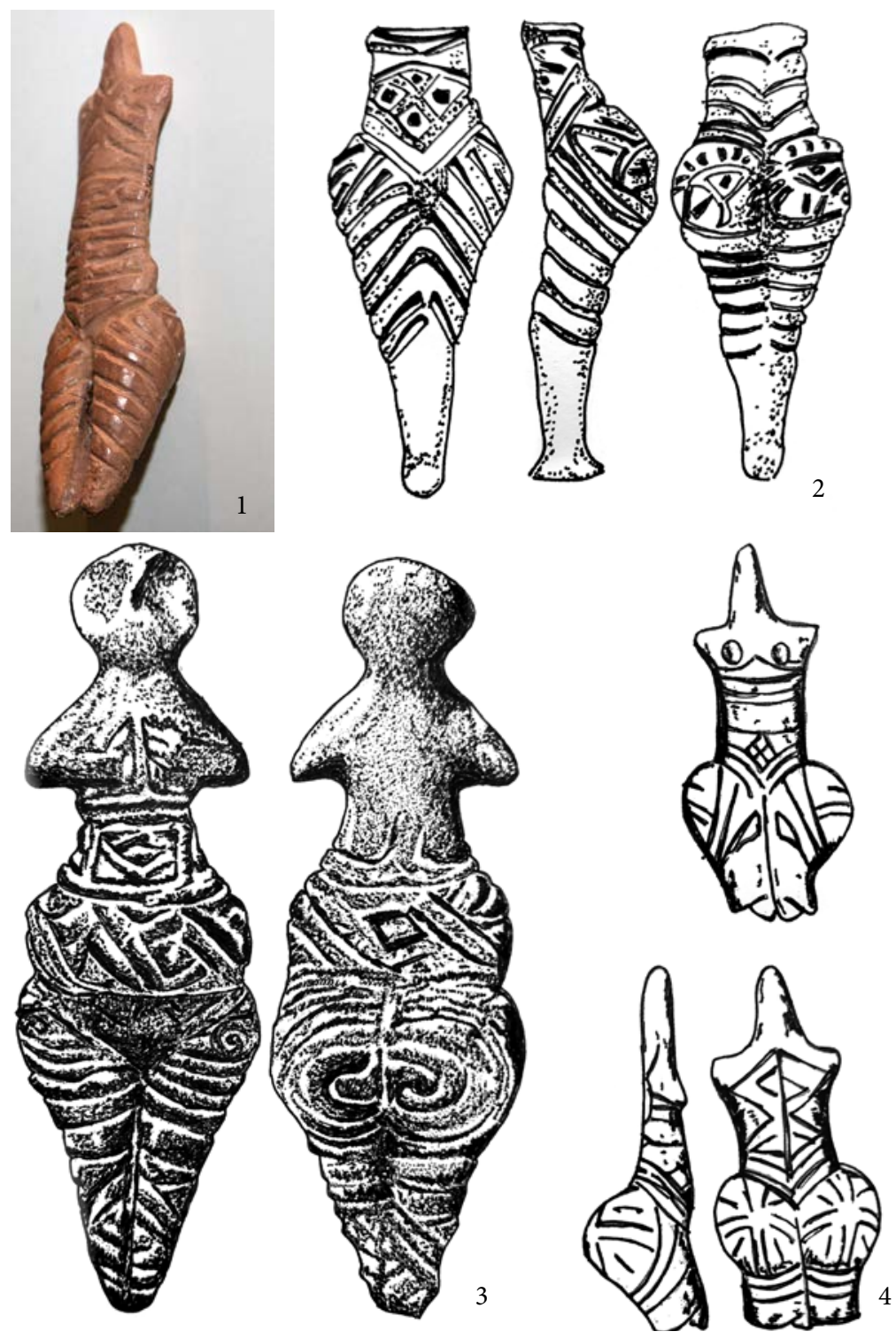

Fig. 6. The decorations of the figurines might depict body modification such as scarification and maybe tattooing (after Gimbutas 2001a; 2001b): 1 - Cucuteni figurine with incision decoration; 2 - Middle Cucuteni clay figurine with incision pattern, H. $7.4 \mathrm{~cm}$, Darguseni-Botošani, NE Romania; 3 - Vinča figurine with incision pattern, H. 16.46 cm, Gradešnica, NW Bulgaria; 4 - Cucuteni, clay figurine, H. 11.7 cm, Novye Ruseshty I, Moldova. Clay figurine with decorative pattern, H. 16.46 cm, Vinča culture, Gradešnica, NW Bulgaria. Photo by Cristian Chirita (available from: https://commons.wikimedia.org/wiki/File:SoborulZeitelor3Cucuteni. JPG). Drawings by Julia Mattes.

6 pav. Figūrèlių dekoras, galimai vaizduojantis kūno puošybą randais ir tatuiruotemis (pagal Gimbutas 2001a; 2001b): 1 - Kukutenio kultūros figūrèlè su îpjovomis; 2 - figūrèlè su ípjovų raštu (aukštis - apie 7,4 cm). Vidurio Kukutenio kultūra. Drăguşeni, Botoşani, šiaurès rytų Rumunija; 3 - figūrèlè su ịpjovų raštu (aukštis - 16,46 cm). Vinčos kultūra, Gradešnica, šiaurès vakarų Bulgarija; 4 - molinè figūrèlè (aukštis - 11,7 cm). Kukutenio kultūra. Novyje Rusešty I, Moldavija. Cristian Chirita nuotr. (prieiga per: https://commons.wikimedia.org/wiki/File:SoborulZeitelor3Cucuteni.JPG). Julia Mattes pieš. 
the Karanovo IV, Kalojanovec, near Nova Zagora, Bulgaria (Fig. 3:3-4), which are completely covered in parallel lines, spirals, and a design emphasizing the roundness of the buttocks, could have also served as a memory storage for the tattooer, made to remember his or her design idea for a full body suit. In this case the figurine would serve the same function as the artist's flash book today: the conservation of a complex cognitive achievement, in this case an elaborate design.

If the decorations of the figurines would be depictions of actual tattoos we still do not know their meaning. According to history and cultural anthropology, tattoos can have a purely decorative function, can mark a social status such as membership of a certain family/clan/village/ethnic group, as well as an individual social status, e. g. identify the wearer as a married person. They can be visual signs of high rank, power, might or status but also mark a person as property, as a slave, or (political) prisoner. Some tattoos can have a religious meaning, for example among Buddhists or Christians, e. g. pilgrim tattoos from the 15th and 16th century (van Dinter 2008, 38). Apotropaic powers are ascribed to the motives: protection from illness, evil (spirits), harm, abduction and the weapons of the enemy, e. g. in Burma and Laos certain 'magic' tattoos are believed to have a bullet proof effect (van Dinter 2008, 75). There are two different expressions of protective effects: one attributes magical properties to the tattoos, while the other serves to disenchant the modified person, hence make him/her unattractive to his enemies and so protect from acts of violence such as human robbery and rape.

Tattoos were also used in medical and therapeutic processes. The process of body modification also holds a psychosocial component as it can be executed as a form of mental training, to practice strength, courage and pain resistance.

Some anthropomorphic female figurines, e.g. the Middle Cucuteni clay figurine from Drăguşeni,
Botoşani, NE Romania (Fig. 6:2) and the Vinča figurine from Gradešnica, NW Bulgaria (Fig. 6:3-4) show a decorum made by impressions 'in the flesh' that would, if this was a real human body, resemble scarification.

This procedure of body modification is known from diverse ethnic groups, e. g. from the West coast region of Africa (van Dinter 2008, 198). Some sources state the most painful, usually large, body modifications - scarification or tattoos - among some ethnics were for women to train braveness and pain resistance for menstruation and a possible later childbirth, while men, not in need for such, were meant to undergo smaller procedures (van Dinter 2008). Other ethnographic records report that in some cases, scarification seems exclusive for women, e. g. among the Abelam people of the Sepik region of Papua New Guinea (Hauser-Schäublin 1989, 149). This could resemble the female figurines of the abovementioned Dumeşti set: While the men show no signs of body modification and instead seem to wear textiles, the five female corpora (and the lower half of a sixth one), are completely covered with lined patterns, which must have been created either by (string?) impressions or carvings into the clay. On a real body, such pattern could only be produced by the method of scarification. It is generally possible that the Neolithic people of South East Europe applied such scar decorations but maybe not in the same extent as depicted on the figurines. Due to their huge size, covering the whole body they would have been extremely dolorous. The author studied several ethnographic picture sources on which the scars show parallels in size and thickness, but could not find examples of such extreme modifications on the entire body such as the archaeological figurines in question would represent.

Therefore and in consideration of the additional absence of archaeological evidence for tattooing in the respective context, it seems much more likely to the author, that decorations on the figurines 
resemble body painting. This technique has several advantages: The colour can be manufactured quite easily, it can be applied in a rather short time when needed, compared to a tattoo of comparable large size, and most importantly no health issues must be feared.

Clay can quickly made into a paste suitable for body paint. The Cucuteni-Tripolye culture used white (a kaolinite white clay, rich in $\mathrm{TiO} 2$ and quartz), black (acobsite and, in only one sample, black carbon or graphit) and red (a clay rich in Fe oxyhydroxides, hematite and quartz) pigments for decoration of the ceramic (Budgar et al.2010) so why not painting pastes like these onto the body? Bodypaint colour can be of short term or a longer lasting duration, as e. g. is known from henna paintings which can last up to several months.

The application of the body paint could be ritual action in itself or it could be used for a certain purpose e. g. camouflage for hunting, as war paint or for festivities. The pattern might also have changed according to taste or occasion. Certain symbols could connect to seasonal rites or celebrations of the life circle: birth, inauguration, celebration of partnership/ marriage, death etc. Some pattern maybe were not of symbolic but of purely decorative nature as people simply might have considered them beautiful.

To the author, these decorated anthropomorphic figurines discussed above, are not only artistic expressions of the human body, they are furthermore multiple representatives of design concepts and a diverse early human body art.

\section{THE INTELLECTUAL-HISTORICAL AND HISTORICAL BACKGROUNDS}

For many engaging in matriarchy research, Gimbutas construct of the Goddess-religion served and still serves as an ultimate proof for the existence of prehistoric matriarchal organized cultures. This is not only valid for some branches supporting a feminist agenda. Archaeological material has been and still is, used as justification for various agendas in general. This is true for stereotypical sex/gender determined constructions in specific. It is often the tool to determine a 'natural male or female dominance' which, according to its supporters would reach as far back as back to the Stone Age. Regardless of their content, both positions require archaeological material in order to establish a historical justification for the respective supposedly proven form of society being 'the natural one that has always been there'. Both standpoints are ahistorical and both contain reverse sexism. The study of the evolution of humanity began to form in the 19th century. Naturally, the preconception of 'primitive societies' and prehistoric human life was heavily coined by the contemporary Victorian moral and zeitgeist (Pettitt, White 2010; Mattes 2017; 2018). The ideal image of gender roles of the 19th century described the man as an active force in an activity environment outside the home (adventure, education, business, travel) and the woman with a more passive existence, which was exclusively devoted to family and domestic tasks (Hausen 1976, 363-393; Weber-Kellermann 1991, 11-12; Mattes 2017, 233).

Hence, the popular picture of natural male dominance was imagined to be expressed by prehistoric hunting, wife-capturing and 'courtship with a club' (Ruddick 2007, 45-63). Such alleged 'cave men' behaviour was often based on the solemn fact that men alone were considered to be able to hunt or, respectively and, to provide meat. 
In the author's opinion, this historic narrative continues into the recent time Western stereotype where meat often is associated with manliness. "Meat, especially red meat, is an archetypical masculine food" (Sobal 2006, 135). ${ }^{7}$ Wesel denied the existence of matriarchy; he attached greater importance to men because he ascribes the activity of hunting to the male sex alone (Wesel 1980, 80-81.)

In the following, the author demonstrates how identical archaeological material is used to recreate a strictly male, respectively a strictly female sphere, depending on the scholars' individual agendas. In this modus operandi the past is being mobilized in the present as a (pre)historical authority for contemporary efforts to secure the superiority of a particular sex or gender.

Paleolithic caves are excellent examples to illustrate unscientific reasoning of the aforementioned kind. These prehistoric places have seen various interpretation since the 1880 s and illustrate in a striking way how interpretation differs and shifts accordingly to the respective agenda.

A pattern which was already stated above on the example of the figurines. The caves, especially the ones of the Ariège dèpartement in the Pyrénées of southwest France, were associated with hunting and hunting magic which was considered a strictly male domain in research while the matriarchy researchers occupied the Ice Age caves as female only places, which according to their view would be representing the uterus of the great goddess etc. 'The caves, crevices, and caverns of the earth are natural manifestations of the primordial womb of the mother. This (...) goes back to the Paleolithic, when the narrow passages, oval-shaped areas, clefts, and small cavities of caves are marked or painted entirely in red. This red colour must have symbolised the Mother's regenerative organs... Burial in the womb is analogous to a seed being planted in the earth, and it was therefore natural to expect new life to emerge from the old' (Gimbutas 2001a, 151). When focusing on the uterine interpretation of caves, graves and artefacts, the following must be taken in consideration: Much of the matristic symbolism circles around the female reproductive organs. While prehistoric people naturally would have had knowledge about how peoples exterior genitalia would look and basic knowledge on anatomy might could be obtained from gutting prey animals, (how) would they know about the precise function, shape and colour of a cervix, an uterus, the Fallopian tubes and the ovaries? In addition, abstracting visual-spatial ability would be necessary for such cognition, as well as for symbolic constructions of the kind proposed by Gimbutas and others. Was this already executed by people at that time? In any case, the respective art on the cave walls is rather two-dimensional.

\footnotetext{
${ }^{7}$ Jeffery Sobal states, that today even the content of meals has a connection to gender: 'Gender permeates all aspects of life, including food life, and can be examined using singular and multiple models of genderedness. Singular models of masculinity gender-type foods as masculine and feminine, suggesting that men and women 'do gender' by consuming gender appropriate foods.' (2006, ibid.). The average stereotype fitting into this is, that men prefer steak and bacon etc. and generally high calorie food, while women tend to favor salad and meals with low calories. In the author's view, this originates in the 19th century. Etiquette stipulated that women should hold back and eat little, because anything else was considered indecent, since in Victorian morality for women, appetite and eating large portions was equated with sexual interest and licentiousness; concerns judged as inappropriate and shameful for ladies. With more and more women working in the beginning of the 20th century, society was forced to let go of the custom that women could only go outside (and dine) accompanied by men. Now not only workers but also working women needed lunch places. While according locality for men often offered free lunch if alcohol was bought simultaneously, food places, tearooms and restaurants for women only were created to prevent women from inconvenient robust atmospheres and harassment by drunken customers but also to prevent women from 'themselves' by not offering alcohol to not endanger the ladies' decency. The 19th century middle-class dining with its different eating habits for class and gender has been understood as a form of social expression and identity by contemporaries (Newnham-Davies 1899, 149) and still is acknowledged so by cultural historical study (Rich 2011).
} 
Based on these arguments, the interpretation of archaeological sites as uterine seems untenable. It is ahistorical and arises from the projection of knowledge of recent people into prehistory. The idea of the 'tomb is the womb' was applied ${ }^{8}$ but not invented by Gimbutas. It dates back at least to 1921 when the symbolism of the round Barrow was discussed as originally representing the pregnancy of Mother Earth and the chamber and passage symbolizing the uterus and the vagina (Cyriax 1921, 205-214). Considering the time when Cyriax's paper was written, the influence of Bachofen's 'Mutterrecht' stands to reason (cf. below).

Of course, it is redundant to say, that recent archaeologists can not fully reconstruct prehistoric scenarios and thus can not know for certain if there were taboo or restrictions for these places based on the biological sex of people or on their gender. In fact, research can not even be certain, that the prehistoric self-conception was divided into female and male only. Hence, neither of the above-mentioned occupations by the respective position does stand on firm ground.

Considering the fact that there are five sexes in biological terms and many ethnographic sources prove that people of different ethnicity in different times have created a variety of gender, for prehistory, too, it can not be excluded that there might have been more than just the simple divination into 'male' and female' (Mattes 2008, 94). Maybe prehistoric people did not even care (as much) about the sex or gender of a person but instead the social role and, respectively or, the age of an individual was considered much more important as a human considered 'mature' or a 'child'? This can also apply to the restriction of places. Indigenous people often hold initiation rites for coming of age. Some of these events exclude youngsters to participate in rituals, community events or to see the sacred place(s) before their inauguration ceremony. In Indonesia, there are a variety of examples for both sex respectively gender exclusiveness as well as for their égalité when concerning participation of social and ritual events being a ritual specialist (Hauser-Schäublin 1989; Waterson 1990; Mattes 2008, 108-109). Therefore, it cannot be assumed that prehistoric 'special places' were used in a uniform way, but rather in divers ways. Some could have been accessible for everybody, while others could have been restricted to one or several cult specialist(s) who could have been male or female, diverse or considered 'something else'.9

Hence, the concept of 'the man the hunter' and 'the woman the mother (goddess)' seems too simple for research. It is as plain as it is discriminating. Rather, it seems as if the 'modern struggle of the sexes' has been shifted into prehistory, to times from which we do not even know how people perceived themselves.

To emphasize the issue, the author provokes the question: Why not think of 'the huntress' and 'the father'?

Another point of criticism to be targeted on a widespread focal point in matriarchy research is the sheer focus on women in the context of fertility and reproduction. This is discriminating in several

\footnotetext{
${ }^{8}$ To Gimbutas, the shape of elaborate human made grave constructions such as, e. g. mounds or passage graves symbolize a pregnant goddess, respective 'the belly of the Earth Mother' (2001a, 148-149, fig. 230-231) while the floor plans of megalithic graves represent the body of the goddess, resembling goddess figurines, respective a seated or a standing goddess, (2001a, 153, 154-155, fig. 236, 239-240) and a barrow with long corridor symbolises 'the lean bonelike Goddess in her death aspect' (2001a, 157).

${ }^{9}$ Therefore, the author recommends reading ethnographic sources in order to soften the traditional image of gender roles of our own society and thereby broaden the archaeological horizon with regard to possible interpretations, from which the latter can only benefit.
} 
ways. The role of men and children is completely excluded from this picture. The role of women is restricted to reproduction: to fertility and giving birth. This represents women of a certain age group and excludes also female persons before menarche and post climacteric. ${ }^{10}$ It seems like the reversion of the criticized androcentrism. Of course the beginning and the end of each individual are central and fundamental axis of its existence, but there is much more in a life between these two markers: daily provision of nourishment, creation and maintenance of homes including all tools and equipment, healthcare, child rearing, tending to sick, young and old persons, keeping of animals, social and community activities, art creating, fight and defence and so forth.

All this, the whole canon of (prehistoric) life and its tasks, is neglected and excluded by the sheer focus on female parity. 'It seems an obsession' (Kunz 2001, 212).

Parties within feminist studies criticize the reduction of women to their ability to give birth. But many scholars in matriarch research do exactly that: by celebrating and focusing solemnly on this aspect, they exclude women of possibly having been artists, craftswomen, trackers, toolmakers, handy women, huntresses, ritual specialists and warrioresses or at least give them equal credit for their ken and achievements (in other than of parturition experience).

When discussing Homo pictor, the same stereotypical narrative is used as previously pointed out on the example of providing meat. Based on the hypothesis that it was exclusively the man who hunted, all active deeds and doings are ascribed to the male sex (again, the idea springing from the 19th century and earlier). So many researcher assumed automatically a Paleolithic creative human must have been male. 'Most traditional authors assume that the depiction of biological and essential female traits meant that females in the Upper Paleolithic were themselves the objects not just of image-making but of social control and male desire; that their place and functions in Paleolithic society were biologically determined and determinative; and that women's status was therefore less cultural and less central to the highly-valued arenas of artistic production, political control, and other domains of social and ritual power' (Tringham, Conkey 1998, 26).

While it is understandable from a historic perspective, that the traditional gender roles of the 1880s-1950s zeitgeist produced common academic statements such as the male (hunter), performing magic and who painted 'Der Jäger der Eiszeit (...) nahm seine Gedanken über die Jagd mit sich, nahm seinen Zauber mit sich, seine Bildkunst (...)' (Kühn $1952,202)$ and never even mention women in this context, it is not comprehensible that this narrative continues into present day research where it still reproduced unreflected: Vierzig, i. a., explicitly determines Stone Age artists as male (2009, 50). '(...) der Jäger sieht das Bison und malt es nach Kriterien der Ähnlichkeit auf die Höhlenwand ab. (...)' (Hildebrandt 2011, 81).

A different approach was made by Snow, who by sexual dimorphism in human hands, suggests, that three-quarters of the hand-negatives in Upper Paleolithic caves of Southern France and Spain belong to female individuals and hence suggests, women significantly took part in producing cave art (Snow 2013). Additionally, one of few hypothesis that ascribes the role of artists to women in the Paleolithic was introduced by McCoid and MCDermott (1992), who furnished an alternative interpretation on Paleolithic figurines, based on the 'autogenous' angle of view which some figurines have been made from: It would

\footnotetext{
${ }^{10}$ The exact same but opposite focus of archaeology on the man in his prime can be observed e.g. on the example of Scandinavian Iron Age research (cf. Ekman, below).
} 
be the perspective of a woman, looking downward on her own body and the 'venus-figurines' would be self-representations (McCoid, MCDermott 1992).

The previously demonstrated is not only limited to the Stone Age but also draws its circles into many periods and issues of archaeology.

Olsen states about the Indo-European research: 'We know the men of the ruling classes write history. So, therefore, we know a lot about boys and men that were free men. We know a lot less about women, practical nothing about children and a lot less also about individuals of the nonpriviliged classes. (...) And its in many ways not so much different today. We talk about a woman writer or a woman painter, you would very rarely talk about a male writer or a male painter.'11 Concerning Swedish Iron Age research, male researchers also criticize the selective focus on the man in the prime of his life. 'The homespunHe-man (...) A creature of thought, a mix of heroes from Icelandic Sagas and the idealisied manhood of Victorian academics (...). However, the dogma of the nobleman still dominates Archaeological research in Sweden. His shadows hides women, children (...) ie the people that really mattered' (Ekmann 2001, 3). This is the exactly identical above mentioned perspective of the matriarchy advocates, only with exchanged content: 'female' was traded for 'male'.

These are only a few of the many examples that have their origins in the intellectual history of the past centenaries. This is based on a structural problem, as archaeology as a subject developed during the 19th century and many interpretations within the discipline have grown historically. Archaeological research has neither reflected sufficiently on its intellectual history, nor questioned traditional interpretations, among them, these gender stereotypes sufficiently. Instead they are reproduced uncritically.
The role and activities of women are still too seldom issued, if then often within the framework of divinity, matriarchy or domesticity and fertility. The mere fact that the 'women's issue' is usually not approached as a normal research subject, but often is understood as a 'case for feminist archaeology' speaks for itself. The overall androcentric focus leads to a neglect of issuing women and children, results in the fact that disciplines outside the subject broach the issue and thus arrive at distorted archaeological results.

\section{MATRIARCHY, RESEARCH HISTORY AND THE IMPACT OF GIMBUTAS' WORKS}

Marija Gimbutas' reconstruction of Old Europe's social structure 'was matrilineal, with the succession to the throne and inheritance passing through the female line. The society was organized around a theacratic, democratic temple community guided by a highly respected priestess and her brother (or uncle); a council of women served as governing body. In all of Old Europe, there is no evidence for the Indo-European type of patriarchal chieftainate' (Gimbutas 2001b, 125). Although Gimbutas was the archaeologist to take up the subject of a past gynocentric society in prehistoric archaeology, the core idea of a respective society structure has a much older history.

Besides being a phenomenon discussed for different ethnic groups, matriarchy as a theme has a long intellectual history. It already occurs in texts of antiquity, e. g. in Herodots' writings (Röder 1998, 299) and is connected the amazon phenomenon which is mentioned in e.g. Homer's Ilias, the adventures of Heracles, the Trojan Wars and the Alexander Novel. Antique paragon of the amazons are found in painting, in sculpture, in relief and of course in red-figure and black figure ceramic. Paintings on a

\footnotetext{
${ }^{11}$ B. Olsen. The Indo-Europeans and the Second Sex. Talk at Indo-European Language and Culture symposium, Center for Studies in Indo-European Language and Culture, Stockholm University, 16 September 2021.
} 
7th century Greek ceramic votive shield is considered the first depiction of fighting Amazons (Krauskopf 2010, 39). Other examples from antiquity are of Greek, Etruscan and Roman origin. The stylistics are Greek, Scythian and Persian influenced (Krauskopf 2010, 42-46). A few Medieval illuminations take up the Amazon topic, among it the depiction of Penthesilea, when referring to texts of antiquity (Mattes 2018, 6-8, fig. 2-5).

The idea of a society ruled and dominated by powerful females often was considered a perversion or reign of terror during many periods in European history. As loathed as the thoughts around this society model was, it aroused interest in the fine arts in contradiction. European women of power and some upper class women occasionally chose to be portrait in the manner of a mythological role portrait, often in the form of classical figures like Athena, Diana or as an Amazon, to emphasize their position and status during the renaissance and baroque, periods in European art strongly referring to antiquity. But it was not before the following epochs before these kinds of picturing became more frequent. In contradiction to the detested society model, the fancy Amazon depictions of the 18th, 19th and 20th century were conducted aesthetically pleasing and often eroticized: Bare breasted beautiful (nude) woman riding on horseback ${ }^{12}$. As the topic became more and more common in fine art and literature, these two seemed to function as incentive for scholarly work. Descriptions by travellers, missionaries and explorers on matriarchal structures mounted during the 18 th century. So over time, the outrageous suspicion dawned on scholars that this suspected 'single case anomalies' could in fact be normal forms of social organization. 'This was outrageous because it questioned and challenged the hitherto so believed male dominated God given order of all times and revealed it as a human made social construction' (Röder 1998, 299).

The introduction of the matriarchy theme into the humanities did not take place before the 19th century, especially by the stimulus of Johann Jakob Bachofens opus. His thesis the 'Mutterrecht (Bachofen 1861) postulates an original matriarchal age of humanity and is one of the first attempts to explain matriarchy scientifically. This opus magnum is central to the research history of the topic and influenced especially social history, psychology and literature in the 19th century. Heavily criticized at first, his work therein after affected Lewis Henry Morgan, Friedrich Engels and later also August Bebel, Erich Fromm and Carl Gustav Jung. Later, the philosopher Simone de Bauvoir expressed concerns about the focus on the mother role and rejected the matriarchal theses as an ideological trap (de Bauvoir 1951).

Bachofen's thesis eventually left the academic circle to be embedded in peoples' every day life, e. g. in the socialist workers' movement where the role of women represented an important issue (Röder 1998, 300).

Eventually the idea that prehistoric societies were matriarchal organized became a broad consensus in research. 'Das Mutterrecht' is a work that became not only well established as common in most humanities but also in general education in the 1920 s and 1930s (Röder 1998, 301). It significantly influenced modern spiritual feminism and modern matriarchy

\footnotetext{
${ }^{12}$ Exempli gratia the following paintings: Die Amazonenschlacht, oil on canvas, $405 \times 693 \mathrm{~cm}$, Anselm Feuerbach, 1873 , Germanisches Nationalmuseum; Zwei Amazonen auf der Hirschjagd, oil on canvas, 60 x $86 \mathrm{~cm}$, Franz Müller-Münster, 19th century, private owned; Zwei Amazonen, oil on canvas, Franz Müller-Münster, 19th century, private owned; Ritt am Strand, oil on canvas, 110 x $100 \mathrm{~cm}$, Christian Speyer, 19th/early 20th century. Notably is the fact that none of the depicted Amazons has an amputated breast. The following sculptures represent Amazons: The fighting Amazon, a huge bronze sculpture guarding the entrance of the Altes Museum in Berlin, by August Kiß from 1842 and the famous Amazon sculptures by Franz von Stuck which exist both in monumental proportions and as small-scale bronze sculpture: Kämpfende Amazone, Sculpture August Kiß, 1842; Reitende Amazone, Franz von Stuck, 1897.
} 
research as well as some branches of feminist studies. 'In the Library of European scholarship the first recognition of such a matristic order (...)' (Gimbutas 2001a, XIII).

Her works joined the themes' research history during the 1980 s. ${ }^{13}$ Roughly a decade later, Chapman, Tringham and others followed. Gynocentric peaceful artistic Neolithic cultures contrasting more aggressive, destructive patriarchal societies became a fashion (Hayden 1986; Tringham 1991; Chapman 1996; 1997).

Although the history of matriarchy in ancient cultures is closely connected to prehistoric archaeology, except for Gimbutas, this topic was and is rarely taken up (here credit goes to B. Röder, J. Hummel and B. Kunz for dealing with the issue in German-speaking research, e.g. 2001). Instead, other disciplines turned and turn to it, misunderstanding archaeological sources and contexts, counting them as axiomatic proof of a previous existing matriarchy, which leads to great misinterpretations and falsified pictures of prehistory e. g. Matriarchy Studies, History, Language and Literature (Jakubin 2013). Alike Bachofen's work, Gimbutas opus also stimulated research outside archaeology and reached a significant number of people outside the academic circle.

Hayden explains the popularity of this prehistoric utopian vision in the face of the coeval Cold War thread. 'However, in the contemporary climate of nuclear war threats and accelerating changes in women's status, it is easy to understand why such interpretations might become increasingly popular' (Hayden 1986, 17). Meskell also states a collective 'contemporary search for a social utopia' $(1995,74)$. Thornton laments '(...) the selfhelp works (...) transform the ancient "goddess wisdom" into therapeutic solace for the angst-ridden middle class. (...) One might be tempted to dismiss Goddess worship as another transitory New Age fad flourishing among the tabloid semi-literate. Unfortunately, Goddess worship is strongest in the presumed bastions of clear thinking and rational discourse, the universities' (Thornton 1999, 72).

Gimbutas' idealized picture of prehistory, in the author's view, has a possible background as a coping mechanism in connection to her biographic encounter with the events of WW $\mathrm{II}^{14}$, suddenly served as a coping mechanism for contemporaries menaced by the nuclear threat of the Cold War. It provided a comforting past utopian vision for a better future. So to speak a comfort, passed on from one generation of survivors to the next.

This was not the only parameter, interacting with the success of Gimbutas' books. She published her works in a popular scientific way and showed media exposure, e. g. by making frequent appearance in interviews. The 1986-1991 cable TV-Series The Goddess In Art, advertised by the producers as 'Dedicated to the Return of the Goddess, the series explores the legacy of this oldest tradition in art and the resurgence of feminist spirituality in contemporary art. Starr Goode interviews scholars to uncover Her suppressed history and artists who are inspired by a radical re-imagining of the feminine' and presented Marija Gimbutas, who had several appearances in this format as 'One of the greatest scholars of the twentieth century,' (https://www. starrgoode.com/TVSeries.html 5.12.2020) and further 'Marija Gimbutas through her work as an

\footnotetext{
${ }^{13}$ Gimbutas' gynocentric perspective clashed with an androcentric one, when she first published her volume The Gods and Goddesses of Old Europe, 7000-3500 BC in 1974. According to an interview with Gimbutas, 'the publishers Thames and Hudson persistent it as 'improper' to allow Goddesses to be first in the title' (Marler 1996) although the majority of images in the book depicts female content (Marler 1996, 45, 10).

${ }^{14}$ It becomes very clear when reading Milisauskas Marija Gimbutas: some observations about her early years, 1921-1944 (2002) and consulting standard works of psychology, such as Hautzinger et al. 2016, 230.
} 
archaeologist uncovered the symbolic language of the Goddess and provided a foundation for feminist spirituality' (ibid.).

Through the popular scientific work and the media presence Gimbutas became a prominent public intellectual figure. This not only resulted in publicity for the women's' history and feminist topics but also certainly stimulated a wide-ranging broad public interest in archaeology in general.

It is not surprising that this idea of prehistory and a goddess centred religion was happily adopted by feminist studies, especially by matriarchy researchers but also outside the universities. It made its way into several socio-political movements, e. g. into parts of the New Age movement, the cultural and spiritual feminism and the eco feminism, which sought to combine faith in women's power with environmentalism, mysticism and neopaganism. It was a fruitful seed on a traditionally neglected issue: 'The current interest in the Goddess is not purely academic, but stems from a desire to remedy the results of millennia of misogyny and marginalization in both religious and secular spheres' (Frymer-Kensky 1992, VII; Meskell 1995, 75). Gimbutas concept of a peaceful past religion had hit a nerve among contemporaries. Many felt a necessity for a spiritual alternative draft to the bloody history of the Church. The earth-centred harmonious Goddess-religion offered refuge and a counterbalance to the remote, punitive male God of western religions (FrymerKensky 1992; Spretnak 1996). Gimbutas spiritual interpretation of archaeological objects and places even motivated people to pilgrimage. A 1977 report describes a woman, who, equipped with Gimbutas books, journeyed to Grapceva Cave on Hvar Island in former Yugolavia to perform rituals (Klein 2009, 575). Numerous Goddess-tourists, especially from
USA, travel to Malta to worship in the neolithic temples, a circumstance scorned by archaeologists but embraced by locals for the possibility of good business, including the sale of Goddess-statues' souvenirs (Rountree 2001).

The fascination for the past world religion did not stop after the decrease of the wide spread Western esotericism wave. In fact, it continues. 'The goddess people, a sort of new age tourists who visit Çatal Höyük and to whom the archaeological site is a place of a continuing cult. They asked us to build a temple next to the site and questioned if it is a good thing to excavate the site because it may disturb the goddess. I remember that they said to us, instead of excavating, dancing is much better.'15

Gimbutas thesis furnished also basis for a quickly growing feminist movement in the United States.

The originary myth created by Gimbutas, seemly scientifically proven as prehistoric reality furnished the legitimacy to reinstall women's power and cultivated the hope that the lost pre-patriarchal culture could be restored. 'The work (...) has been crucial to the growth of feminist spirituality, feminist religious scholarship, feminist psychology, and the liberating implications that the existence of a goddess tradition can bring to women everywhere (...). Gimbutas' work helps us entertain the hope that the oppression of patriarchy did not always exist' (Murdock 2014, 943-944).

The second wave of feminism in the US is considered as a delayed reaction against the renewed domesticity of women in the consequence of the postwar period. It drew attention to domestic violence, harassment and (sexual) violence in general. As a consequence the first women's shelter in the modern world, Haven House, in California opened its doors in 1964. The US Emergency Shelter Program was

\footnotetext{
${ }^{15}$ Nurcan Yalman, Nişantaşı Dep. of History, University Istanbul. Talk: Marija Gimbutas and Çatal Höyük: New Interpretations of Symbols. Conference Marija Gimbutas in Lithuania and the World: A Centenary. Lithuanian Institute of History, Lithuania, April 29-30, 2021.
} 
established in Hayward, California in 1972. Since, it offers practical help and legal support for people at risk of domestic violence, regardless of their sex and gender.

The movement was a strong and successful one. Men and women founded the National Organization for Women in 1966. The fight for more equality brought changes in custody laws and divorce law. The Equal Pay Act of 1963, Title VII-equal employment opportunity of the Civil Rights Act of 1964 and finally a law requiring the US Military Academies to admit women in 1975 and the longtime ban on women serving in US military combat roles had been lifted in 2013. All these efforts eventually resulted in less prejudice and a change of social attitudes.

A similar development took place approximately isochronal in the European countries.

The gynocentric narratives not only influenced the English-speaking countries but also Germany until present. Heide Göttner-Abendroth, the central scholar in Modern Matriarchal Studies joined the second-wave feminism and is considered one of the pioneers of women's studies in West Germany. In 1986 she founded the International Academy for Modern Matriarchal Studies \& Matriarchal Spirituality (HAGIA). With few exceptions her work is receipted very critical within university academia. Göttner-Abendroth's publications (2019) show clear signs of being inspired by Gimbutas. One of them concerns 'matriarchal landscape-mythological research', comprising a comprehensive method of an 'intellectual archaeology' (Göttner-Abendroth 2014) ${ }^{16}$ Both, term and method are clearly based on the archaeomythological method. It efforts to provide the incontrovertible proof of the existence of a prehistoric matriarchy using resources from multidisciplinary ingredients. For this purpose, complete ignorance of basic archaeological knowledge, be it method or archaeological cultures, is used. These attempts are a mix of esoteric mysticism and feminist Utopian theories of matriarchy which are inspired by legends whose truth content is nebulous

The following paragraph takes a look on the influence of Gimbutas works in her mother country.

The outline of the feminist movement' $s$ development of the post-socialist countries, especially like smaller ones such as Lithuania, according to Navickaite, is poorly documented and only sparsely theorized.

Although Marija Gimbutas herself stated 'I was not a feminist and I had never any thought I would be helping feminists' (Larsson 2015), Navickaite found out during research for her $\mathrm{PhD}$ thesis on Lithuanian post-socialist women's movement, that Gimbutas is mentioned in quasi every feminist text published during the 1990s, referencing her academic achievements and specially the theory of a matristic Old Europe (Navickaite 2019, 224). Besides of course Gimbutas, considered a folk hero, was naturally an icon to turn to, Navickaite explains this development as follows: '(...) Gimbutas became the heroine for the emerging post-socialist feminism in the 1990s Lithuania, (...) her ideas and person were taken up by feminists in the construction of a range of feminist strategies and discourses (...) Lithuanian feminists managed to combine their emancipatory goals with the two most pervasive yet seemingly contradictory discourses of post-socialism: the narrative of Western-orientated modernization (...) and the narrative of nationalist retraditionalization

\footnotetext{
16 'Landscape mythology research is using the example of German landscapes. Here, material relics of the Neolithic/ Bronze Age cultural layer are being analyzed and linked to the surrounding landscape. This requires the extensive method of intellectual archaeology, which the author [Göttner-Abendroth, author's note] has developed through years of intensive study both at home and abroad. She not only links archaeology and geography statements, but also uses mythology, folklore (folklore and customs) and language studies in an interdisciplinary manner. In this sense, the matriarchal landscape mythology is a partial area of securing evidence for early historic matriarchal cultures' (ibid.)
} 
(...) it was the ambivalence of Gimbutas' person and her ideas about women's role in society, femininity and masculinity, about the origins of the nation and European belonging, among other things, that made her theory of Old Europe so easily moldable for a variety of ideological purposes, adding gender elements into both the narratives (...)' (Navickaite 2019, 226).

Another interesting result of Navickaite that opens up a new perspective on the relationship between Gimbutas person and her opus, is that the latter associated herself with a ragana ${ }^{17}$ since the 1970s. '(...) aimed to reclaim the word and the figure of ragana or ragius, therefore implying herself to be a sort of female prophet with an exceptional ability to see beyond material artefacts and dry facts. By referring to herself as ragana Gimbuas established an affinity with the heritage of the mythological supernatural female power, which has been, she thought in line with many feminist thinkers, feared and despised by modern masculine science as well as Christianity. It would be interesting to research on Gimbutas relationship to spirituality and Christianity in this context. In a Lithuanian language response to a '(...) well-known Lithuanian folklorist, Gimbutas similarly implied to be gifted with poetic and visionary powers of ragana' (Navickaite 2019, 143). Gimbutas not only had to face strong academic opposition, she saw herself confronted several times with the argumentum ad hominem against her persona. Navickaite points out that Gimbutas, probably seeing and seeking parallels between this powerful Goddess who was demonized and degraded into the familiar, publicized image of a witch 'Gimbutas who aimed to reverse the modern norms, which were applied to the understanding of prehistoric mythology, personally empathized with the degraded images of the Goddess, and in a way aimed to 'channel' the values of the Goddess-centred Old Europe in her own scholarly work' (Navickaite 2019, 145).

\section{CONCLUSIONS}

Analogue to Gimbutas, the anthropomorphic Neolithic figurines of South East Europe are frequently considered as Goddesses and connected to fertility, even if their sex determination is not evident. They still move in the field of tension between divinity, domesticity and fertility. Although decades have passed since Gimbutas' works were published, no major changes within the discipline can be stated in this regard.

By means of stylistic analysis and selected ethnographic analogies, an application-related interpretation of the Poduri-Dealul set as an ancestral council was furnished. Further, by means of these methods, it was elaborated that the decorations on the Cucuteni, Vinča and some Karanovo figurines can be representatives of human body art: Painted figurines can signify tattooing or body painting while incisioned figurines might resemble scarification and in some cases a memory storage for the artist to conserve a complex design.

The analysis of interpretations of the archaeological material utilized by Marija Gimbutas for her Goddess thesis and their intellectual-history showed, that the identical interpretative structures are being applied according to the respective agenda: by both the gynocentrist and the androcentrist opposition. Traditional 19th century stereotypical gender roles are still reprocicated unreflectively and persist stubbornly in various archaeological subject areas. To date, a considerable shortfall of

\footnotetext{
${ }^{17}$ Ragana/Ragius: In Lithuanian folklore, a person with special gifts and supernatural powers. Etymologically related with the word 'to foresee'. To Gimbutas and other scholars, Ragana described a Lithuanian Pagan Goddess of death and regeneration who was demonized in the Christianisation process of the country (Navickaite 2019, 144).
} 
broaching women related issues in archaeological scholarship is to be lamented. This neglect results in the fact that other humanities disciplines outside the subject broach the issue and thus arrive at distorted archaeological results.

The author therefore understands this paper as a plea for a more frequent and refined discussion of the various roles of women in prehistory and not to be left to pseudo-scientific treatment, but to be researched neutrally and scientifically.

\section{Acknowledgements}

The Author would like to thank Agnè Čivilytè, Dirk Brandherm, Pham Thai Ho, Leo Peters, Gesa Ruge and the anonymous reviewers for their useful remarks that helped improve the quality of this manuscript.

\section{REFERENCES}

Adler, M., 2006. Drawing Down the Moon: Witches, Druids, Goddess-Worshippers, and other Pagans in America (4th edition). New York: Penguin Books.

Bachofen, J. J., 1861. Das Mutterrecht. Eine Untersuchung über die Gynaikokratie der alten Welt nach ihrer religiösen und rechtlichen Natur. Stuttgart: Verlag von Krais und Hoffmann.

Bailey, D. W., 1994. Reading Prehistoric Figurines as Individuals. World Archaeology, 25 (3), 321-331.

Bailey, D. W., 2010. The Figurines of Old Europe. In: Anthony, D. W., Chi, J. W., (eds.). The Lost World of Old Europe. The Danube Valley, 5000-3500 вс. New York: Institute for the Study of the Ancient World, 113-127.

Bailey, D. W., 2013. Ceramic Female Figurine. Archaeologie, A publication of the Archaeological Institute of America. Available from: https://www.archaeology.org/exclusives/ articles/1349-cucuteni-figurine-romania-neolithic.
Beauvoir, de, S., 1951. Das andere Geschlecht. Sitte und Sexus der Frau. Hamburg: Rowohlt Verlag.

Biel, P. F., 1996. Symbolic communication systems: symbols on anthropomorphic figurines of the Neolithic and Chalcolithic from south-eastern Europe. Journal of European Archaeology, 4, 153-176.

Carlie, A., 2004. Forntida byggnadskult. Tradition och regionalitet $i$ södra Skandinavien. Riksantikvarieämbetet (=Arkeologiska Undersökningar. Skrifter Nr 57). Stockholm: Riksantikvarieämbetets förlag.

Chapman, J., 1996. Enchainment, Commodification and Gender in the Balkan Neolithic and Copper Age. Journal of European Archaeology, 4, 203-242.

Chapman, J., 1997. Changing Gender Relations in the Later Prehistory of Eastern Hungary. In: Moore, J., Scott, E., (eds). Invisble People and Processes: Writing Women and Childhood into European Archaeology. Leicester: Leicester, 131-149.

Cyriax, T., 1921. Ancient Burial-Places: A suggestion. Arch. Jour. Lxxviii, for 1921, 205-215.

Dumitrescu, V., 1979. Arta Cultura Cucuteni. București: Editura Meridiane.

Dumitrescu, R., 2008. Neolithic codes - a different approach of Cucuteni woman (Paraarchaeological and para-medical meditative essay). In: Coimbra, F., Dimitriadis, G., (eds.). Cognitive archaeology as symbolic archaeology. Oxford, BAR, International Series 1737, 47-50.

Eller, C., 2006. The Myth of Matriarchal Prehistory: Why an invented past won't give women a future. Boston: Beacon Press.

Evans, J. D., 1959. Malta. London: Thames \& Hudson.

Friedmann, R., Antoine, D., Talamo, S., Reimer, P. J., Taylor, J. H., Wills, B., Manniono, M. A., 2018. Natural mummies from Predynastic Egypt reveal the world's earliest figural tattoos. Journal of Archaeological Sciences, 92, 116-125. 
Frymer-Kensky, T., 1992. In the Wake of the Goddesses: Women, Culture and the Biblical Transformation of Pagan Myth. New York: The Free Press.

Furholt, M., 2018. Massive Migrations? The Impact of Recent aDNA Studies on our View of Third Millennium Europe. European Journal of Archaeology, 21 (2), 159-191.

Gimbutas, M., 1946. Die Bestattung in Litauen in der vorgeschichtlichen Zeit. Tübingen: Verlag $\mathrm{H}$. Laupp.

Gimbutas M., 1968. Interview. In: Marler, J., 1996. The Life and Work of Marija Gimbutas. Journal of Feminist Studies in Religion, 12 (2), 37-51.

Gimbutas M., 1992. The Civilization of the Goddess. The world of old Europe. San Francisco: HarperCollins.

Gimbutas, M., 1997. The Living Goddesses. Berkeley, London: University of California Press.

Gimbutas, M., 2001a. The Language of the Goddess. London: Thames \& Hudson Ltd.

Gimbutas, M., 2001b. The Living Goddesses. Dexter, R., Berkeley, M., (eds). London: University of California Press.

Goode, S., 1986. Interview with Marija Gimbutas - The Goddess in Art TV Series [TV-series], Cable TV, USA [online]. Available from: https:// www.starrgoode.com/gimbutus2.html [Accessed 20 October 2020].

Göttner-Abendroth, H., 2014. Matriarchale Landschaftsmythologie. Von der Ostsee bis Süddeutschland. Stuttgart: Kohlhammer Verlag.

Göttner-Abendroth, H., 2019. Geschichte der matriarchale Gesellschaften und Entstehung des Patriarchats. Band III: Westasien und Europa. Stuttgart: Kohlhammer Verlag.

Haak, W., Lazaridis, I., Patterson, N., Llamas, B., Brandt, G., Rohland, N., Mallick, S., Nordenfelt, S., Harney, E., Stewardson, K., Fu, Q., Mittnik, A., Bánffy, E, Economou C., Francken, M., Friederich, S., Garrido Pena, R., Hallgren, F., Khartanovich, V., Khokhlov, A., Kunst, M., Kuznetsov, P., Meller, H.,
Mochalov, O., Moiseyev, V., Nicklisch, N., Pichler, S., Risch, R., Rojo Guerra, M., Roth, C., SzécsényiNagy, A., Wahl, J., Meyer, M., Krause, J., Brown, D., Anthony, D., Cooper, A., Alt, K. W., Reich, D., 2015. Massive migration from the steppe was a source for Indo-European languages in Europe. Nature 522, 207-211. DOI: https://doi.org/10.1038/nature14317.

Hansen, S., 2003. Archäologie zwischen Himmel und Hölle. Bausteine für eine theoretische reflektierte Religionsarchäologie. In: Heinz, M., Eggert, K. H., Feith, U., (Hrsg.). Zwischen Erklären und Verstehen? Beiträge zu den erkenntnistheoretischen Grundlagen archäologischer Interpretation. Beiträge einer Tagung in Freiburg 1998. Tübinger Arch. Taschenb. 2. Münster: Waxmann, 113-148.

Hansen, S., 2007. Bilder vom Menschen der Steinzeit. Untersuchungen zur anthropomorphen Plastik der Jungsteinzeit und Kupferzeit in Südosteuropa (=Archäologie in Eurasien, 20). Mainz: Philipp von Zabern.

Hauser-Schäublin, B., 1989. Kulthäuser in Nordneuguinea. (=Abhandlungen und Berichte des Staatlichen Museums für Völkerkunde Dresden Forschungsstelle, Bd. 43. Monographien 7). Berlin: Akademie Verlag.

Hayden, B., 1986. Old Europe: Sacred Matriarchy or complementary opposition? In: Bonanno, A., (ed.). Archaeology and Fertility Cult in the Ancient Mediterranean: papers presented at the First International Conference on Archaeology of the Ancient Mediterranean, 2-5 September 1985. Malta University, 17-30.

Hildebrandt, T., 2011. Bild, Geste und Hand. LeroiGourhans paläontologische Bildtheorie. IMAGE. Zeitschrift für interdisziplinäre Bildwissenschaft, 14. Available from: https://www.gib.uni-tuebingen.de/ image/image? function $=$ fnArticle $\&$ showArticle $=198$ [Accessed 1st February 2020].

Jakubin, V., 2013. Religija božica u prapovijesti. Available from: https://repozitorij.ffos.hr/islandora/ object/ffos:1159 [Accessed 20 October 2020]. 
Kaika, Z., 2018. Neolithic figurines in Eastern Macedonia. Thessaloniki. Available from:

https://repository.ihu.edu.gr/xmlui/bitstream/handle/11544/29121/NEOLITHIC\%20FIGURINES\%20 IN\%20EASTERN\%20MACEDONIA.pdf?sequence $=1$ [Accessed 5th December 2020].

Klein, J., 2009. Goddess: Feminist Art and Spirituality in the 1970s. Feminist Studies, 35 (3), 575-602.

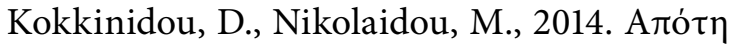

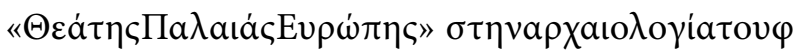

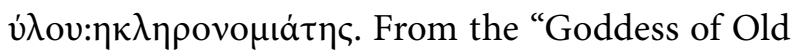
Europe" to gender archaeology: the legacy of Marija Gimbutas. In: Evangelia Stefani, E., Merousis, N., Dimoula, A., (eds.). A century of research in prehistoric Macedonia 1912-2020 (International Conference Proceedings. Archaeological Museum of Thessaloniki 22-24 November 2012). Thessaloniki: Archaeological Museum of Thessaloniki Publications, 695-706.

Krauskopf, I., 2010. Griechisch, skythisch, orientalisch. Das Amazonenbild in der antiken Kunst. In: Historisches Museum der Pfalz Speyer (ed.). Amazonen. Geheimnisvolle Kriegerinnen. München: Edition Minerva, 39-47.

Hageman, J. B., Hill, E., 2016. Leveraging the Dead: The Ethnography of Ancestors. In: Hageman, J. B., Hill E., (eds.). The Archaeology of Ancestors. Florida: University press, 1-43.

Hausen, K., 1976. Die Polarisierung der „Geschlechtscharaktere“ - Eine Spiegelung der Dissoziation von Erwerbs- und Familienleben. In: Conze, W., (ed.). Sozialgeschichte der Familie in der Neuzeit Europas. Neue Forschungen. Stuttgart: Klett, 363-393.

Hem Eriksen, M., 2013. Doors to the dead. The power of doorways and thresholds in Viking Age Scandinavia. Archaeolocial Dialogues, 20, 2, 187-214.

Kunz, B., 2001. Frau Willendorf in Raum und Zeit. In: Röder, B., Hummel, J., Kunz, B., (eds.). Göttinnendämmerung. Das Matriarchat aus archäologischer Sicht. Königsförde/Krummwisch: Königsfurt Verlag, 184-225.
Kühn, H., 1952. Die Felsbilder Europas. Stuttgart: W. Kohlhammer Verlag.

Larsson, H., 2015. Känslor, Narration och Hegemoni Olika perspektiv på diskussionen om Marija Gimbutas'teorier. Available from: http://hdl.handle. net/2077/41022 [Accessed 3rd January 2020].

Mantu, C.-M., Dumitroaia, G., 1997. Catalogue. In: Mantu, D., Tsaravopoulos, A., (eds.) Cucuteni: The Last Great Chalcolithic Civilization of Europe. Thessaloniki: Athena, 179-181.

Marler, J., 1996. The Life and Work of Marija Gimbutas. Journal of Feminist Studies in Religion, 12 (2), 37-51.

Meskell, L., 1995. Goddesses, Gimbutas and 'New Age' archaeology. Antiquity 69, 74-86.

Marinescu-Bîlcu, S., 1981. Tîrpes,ti. From Prehistory to History in Eastern Romania. Oxford: BAR.

Mattes, J., 2008. Frühe Kultbauten. Studien zur Archäologie sakraler Plätze in Südskandinavien (=Aun 38). Västerås: Edita Västra Aros.

Mattes, J., 2017. Drei einzigartige spätwikingerzeitliche Schwertfunde aus Skandinavien. Prähistorische Zeitschrift (Praehistoric Journal), II, 91/2, 219-240.

Mattes, J., 2018. Lagerthas Schwestern? Über Kämpferinnen in der (Früh-)Geschichte und Waffengräber von Frauen in Nordeuropa. Humanities Commons. DOI: http://dx.doi.org/10.17613/hmvd-7j18.

Mattes, J., 2019. Die zoomorphen Abbilder des Neolithikums und der Bronzezeit in Skandinavien. Humanities Commons. DOI: http://dx.doi. org/10.17613/b0v9-7850.

Mattes, J., 2020. Neolithische Kunst der zirkumpolaren Jäger und Sammler Die Figuren der Grübchenkeramischen Kultur und ihre Deutung. $\mathrm{Hu}$ manities Commons. DOI: http://dx.doi.org/10.17613/ b4dd-2e06.

McCoid, C. H., MCDermott, L. D., 1996. Toward Decolonizing Gender. American Anthropologist, 98 (2), 319-326. 
Milisauskas, S., 2000. Marija Gimbutas: some observations about her early years, 1921-1944. Antiquity, 74, 286, 800-804.

Molodin, V. I., 2005. Die Tätowierung bei der antiken Bevölkerung Sibiriens. Mitteilungen der Anthropologischen Gesellschaft Wien, 34/35, 95-114.

Molodin, V. I., Natal'ja V., Polos'mak, N. V., 2007. Die Denkmäler auf dem Ukok-Plateau. In: Deutsches Archäologisches Institut u.a. (ed.). Im Zeichen des Goldenen Greifen. Königsgräber der Skythen. München: Prestel, 140-147.

Moroole, M. A., Materechera, S. A., OtangMbeng, W., Aremu, A. O., 2020. African indigenous contraception: A review. African Journal of Reproductive Health, 24, 4, 173-184.

Murdock, M., 2014. Gimbutas, Marija, and the Goddess. In: Leeming, D.A., (ed.). Encyclopedia of Psychology and Religion. n.p. DOI: https://doi. org/10.1007/978-1-4614-6086-2_9329.

Navickaite, R., 2019. The Prehistoric Godess of the Late Twenties Century. Transnational Feminist Reception, Construction and Appropriation of Maria Gimbutas. Budapest: Central European University. Available from: https://sierra.ceu.edu/search/X?se archtype $=$ a\&searcharg=navickaite + rasa\&submit. $\mathrm{x}=0$ \&submit. $\mathrm{y}=0$ [Accessed 03 January 2021].

Newnham-Davis, Lieut.-Col. N., 1899. Dinners and Diners: Where and How to Dine in London. London: Grant Richards, Office of the Pall Mall Publications.

Olsen, B., 2021. The Indo-Europeans and the Second Sex. Talk at Languages and Myths of Prehistory Symposion, Centre for Studies in Indo-European Language and Culture, Stockholm university, 16.09.2021.

Pettitt, P. B., White, M. J., 2010. Cave men: Stone tools, Victorian science and the 'primitive mind' of deep time. Notes and records. The Royal Society Journal of the History of Science, 65, 25-42.

Probst, E., 1996. Die Lüneburger Gruppe in der Bronzezeit. München: GRIN.
Probst, E., 2011a. Die Adlerberg-Kultur. München: GRIN.

Probst, E., 2011b. Die Singener Gruppe. München: GRIN.

Rich, R., 2011. Bourgeois consumption: Food, space and identity in London and Paris, 1850-1914. Manchester: Manchester University Press.

Ruddick, N., 2007. Courtship with a Club: WifeCapture in Prehistoric Fiction, 1865-1914. The Yearbook of English Studies, 37, 2, 45-63.

Rountree, K., 2001. The Past is a Foreigners' Country: Goddess Feminists, Archaeologists, and the Appropriation of Prehistory. Journal of Contemporary Religion, 16, 5-27.

Röder, B., 1998. "Illusionäre Vergangenheitsaneignung" kontra "patriarchale Verblendung": Matriarchatsforschung und Archäologie in Deutschland. Archäologische Informationen, 21 (2), 299-313.

Röder, B., Hummel, J., Kunz, B., 2001. Göttinnendämmerung. Berlin: Königsfurth.

Samadelli, M., Mellis, M., Miccoli, M., Egartner Vigl, E., Zink, A. R., 2015. Case study. Complete mapping of the tattoos of the 5300-year-old Tyrolean Iceman. Journal of Cultural Heritage, 16, 5, 753-758.

Snow, D., 2013. Sexual Dimorphism in European Upper Paleolithic Cave Art. American Antiquity, 78 (4), 746-761.

Spretnak, C., 1996. Beyond the Backlash: An Appreciation of the Work of Marija Gimbutas. Journal of Feminist Studies in Religion, 12, 2, 91-98.

Thiel, E., 2019. Geschichte des Kostüms: Die europäische Mode von den Anfängen bis zur Gegenwart. Leipzig: Henschel.

Thornton, B., 1999. The False Goddess and her lost Paradise. A Journal of Humanities and the Classics, 7, 1, 72-97.

Tringham, R., 1991. Households with Faces: the challenge of gender in prehistoric architectural remains. In: Gero, J., Conkey, M. (eds). Engendering Archaeology: Women and Prehistory: Women and Prehistory. Oxford: Basil Blackwell, 94-131. 
Sobal, J., 2006. Men, Meat, and Marriage: Models of Masculinity. Food and Foodways, 13 (1-2). DOI: https://doi.org/10.1080/07409710590915409.

Steadman, L. B., Palmer, C. T., Tilley, C. F., 1996. The Universality of Ancestor Worship. Ethnology, 35, 1, 63-76.

van Dinter, M. H., 2008. Tatau. Traditionelles Tätowieren weltweit. Augsburg: Aurun.

Vierzig, S., 2009. Mythen der Steinzeit. Das religiöse Weltbild der frühen Menschen. Oldenburg: BIS-Verlag.

Waterson, R., 1990. The living house. An anthropology of architecture in South-East Asia. Oxford university press.

Watson, E., Gaydarska, B., 2014. Little Cucuteni pots of hope: a challenge to the divine nature of figurines. Studii de Preistorie, 11, 115-124.
Weber-Kellermann, I., 1991. Frauenleben im 19. Jahrhundert. Empire und Romantik, Biedermeier, Gründerzeit. München: Beck.

Wesel, U., 1980. Der Mythos vom Matriarchat: über Bachofens Mutterrecht und die Stellung von Frauen in frühen Gesellschaften. Frankfurt am Main: Suhrkamp Verlag.

\section{ABBREVIATIONS}

GRK - Pitted Ware culture (Swedish:

Gropkeramisk kultur)

STR - Battle Axe culture (Swedish:

Stridsyxekultur)

TRB - (also TBK) Funnel(-neck-)Beaker culture (Swedish: Trattbägarkultur)

\title{
ANTHROPOMORPHIC FIGURINES, GYNOCENTRISM AND GIMBUTAS' RECEPTION INSIDE ARCHAEOLOGY AND BEYOND
}

\author{
Julia Mattes \\ Summary
}

Marija Gimbutas combined two thitherto neglected themes: women and religion. She was among the first archaeologists to take on the subject of a matristic prehistoric society and was, in contradiction to the majority of matriarchy researchers, among the first to deliver a cultural, geographic and chronological frame including a hypothesis for the decline of a particular society. Her hypothesis is mainly based on anthropomorphic (SE European Neolithic) figurines. Notwithstanding the justified methodological criticism, her work stimulated research on these genera.

Since their discovery in the 1880 s, the artefacts have suffered one-sided treatment by research conducted in archaeology and other disciplines which feel compelled to decipher their,true meaning: they are usually interpreted from an androcentric perspective; in the context of fertility or, analogous to Gimbutas, as goddesses. Their aesthetic appearance is either described as divine or as distorted and crude.

On the basis of selected examples, the methods of ethnological analogy and stylistic analysis are used to contribute to the interpretation of the decorations of the SE European Neolithic material.

The author hypothesises that some Cucuteni, Vinča and Karanovo figurines may be representations of early body art: painted figurines resembling body painting, possibly tattoos, incisions could depict scarification. Body modifications 
documented in prehistory, history and ethnography show a range of social, psychological and ritual meanings.

Certain figurines with elaborate full-body ornamentation may also have served as memory storage for the artist / tattooer, made to remember his or her complex cognitive achievement, in this case a sophisticated design.

Analysis of ceramic colours from CucuteniTropolye culture pottery corresponds to the figurines' decorative colouring, which leads the author to suggest the colours were also applied in body painting.

Additionally, an application-related interpretation for the Cucuteni-Tripolye figurines of the Poduri set is proposed: the author disagrees with the interpretation as goddesses, as the sex determination of the figurines remains unclear. The set rather resembles an ancestor council, forming an assembly that would be addressed by people in need of counsel. The difference in size may symbolically point to the importance of the respective figurines. The larger ones, resembling the elders, are equipped with chairs, marking their status by size while the smaller ones are minor in rank. The latter may represent contemporaries, small, as they are the youngest in lineage, who were placed on the laps of the great ones, the ancestors, so that through physical contact the answers to questions posed, the wisdom and strength of the elder symbolically passed into the seekers of help and advice.

Using various examples, the paper demonstrates and criticises both gynocentric and androcentric factions' use of the same archaeological findings and sites for their respective agendas, both making them a tool to determine a natural male or female dominance respectively which, according to its supporters, would reach as far back as the Stone Age. Regardless of their content, both positions require archaeological material in order to establish a historical justification for the respective supposedly proven form of society to be 'the natural one that has always been there'. Many of these arguments and concepts are untenable and arise from recent knowledge being projected onto prehistory. Both standpoints are ahistorical and both contain reverse sexism. Examples are not limited to the Paleolithic and Neolithic but can be found in many periods and subject areas of archaeology. This is based on a structural problem found in the development of archaeology and related disciplines as academic subjects during the 19th century: many interpretations within the disciplines have grown historically. Research has neither reflected sufficiently on its own intellectual history nor has it thoroughly questioned traditional interpretations, among them gender stereotypes. Instead, these are often reproduced uncritically.

Although Gimbutas became the central figure of matriarchy research, the field had already been present in 19th century humanities, based to a large extent on Bachofen's 1861 'Das Mutterrecht', which strongly influenced academia and general education up until the 1930s and established a consensus that prehistoric societies were matriarchally-organised. Parallel to Bachofen's work, Gimbutas' opus influenced many research disciplines and impacted several international socio-political and even religious movements, i. a. New Age. Her contributions even inspired people to pilgrimage to sites featured in her publications, a phenomenon lasting until today. While her work and persona influenced second-wave feminism in the USA, they remain significant for German feminist and matriarchal studies and the post-socialist Lithuanian women's movement until the present. 


\title{
ANTROPOMORFINĖS FIGŪRĖLĖS, GINOCENTRIZMAS IR MARIJOS GIMBUTIENĖS IDE்JOS ARCHEOLOGIJOJE BEI UŽ JOS RIBŲ
}

\author{
Julia Mattes
}

\section{Santrauka}

M. Gimbutienè sujungè dvi iki tol archeologijoje nenagrinètas temas: moteris ir religiją. Ji buvo viena pirmųjų archeologijoje, pradejjusių gilintis ị priešistorès matristinès visuomenès temą. Priešingai nei tuo metu vyravusiuose matriarchinès visuomenès tyrimuose, M. Gimbutienès darbuose pirmą kartą buvo pateiktos kultūrinès, geografinès ir chronologinès tyrimų sintezès ir hipotezè, svarstanti tam tikrų visuomenių žlugimą.

M. Gimbutienės hipotezè rèmėsi neolito laikotarpio antropomorfinių figūrèlių, rastų pietryčių Europoje tyrimais. Nepaisant pagrịstos kritikos, susijusios su metodologija, jos darbas paskatino tolimesnius šios temos tyrimus. Antropomorfiniai dirbiniai, rasti XIX a. IX dešimtm., buvo tyrinèti tik vienpusiškai tiek archeologijoje, tiek kitose disciplinose. Pagrindine šių tyrimų užduotimi buvo laikomas dirbinių reikšmès iššifravimas, o interpretavimas rèmèsi androcentriniu požiūriu: įžvelgiant vaisingumą ar (analogiškai M. Gimbutienei) dirbinius interpretuojant kaip deivių atvaizdus. Šiuose tyrimuose estetinè radinių išvaizda paprastai apibūdinama arba kaip dieviška, arba kaip iškreipta ir grubi.

Pietryčių Europos neolito laikotarpio archeologinès medžiagos puošyba interpretuojama pasitelkiant etnologinių analogų paiešką ir stiliaus analizę.

Autorè iškèlė hipotezę, jog Kukutenio, Vinčos ir Karanovo kultūroms priskiriamos figūrèlès galètų būti patys pirmieji kūno puošybos (piešiniai ant kūno, galbūt tatuiruotès, o įrèžimai galimai vaizduoja randus) pavyzdžiai. Manoma, kad ịvairi kūno puošyba, žinoma iš priešistorès, istorinių ir etnografinių pavyzdžių, turejo ịvairias socialines, psichologines ir ritualines reikšmes. Kai kurios puošniai dekoruotos figūrèlès galèjo būti naudojamos žmogaus, išraižiusio ornamentus ir ženklus, kūrybos įamžinimui, kaip atminties simboliai.

Kukutenio-Tripolès kultūros keramikos analizè parode, kad keramikos puošybos spalvos tokios pat, kaip puošusių figūrèles. Tai leidžia manyti, jog tokios spalvos galbūt galèjo būti naudojamos ir kūno puošybai.

Straipsnyje taip pat aprašomas Kukutenio-Tripolès kultūros Poduri-Dealul figūrèlių rinkinys, ir pateikiama jo interpretacija, paremta objektų pritaikymu. Autorè nesutinka su nuomone, kad figūrèlès vaizduoja deives, kadangi jų lytis yra neaiški. Figūrèlès veikiau primena protèvių tarybą, šaukiančią susirinkimus patarimo ieškantiems žmonėms. Skirtingi figūrèlių dydžiai simboliškai vaizduoja veikejų svarbą: pačios didžiausios yra įtakingiausieji bendruomenès nariai. Didžiosioms figūrèlèms taip pat buvo pridètos kẻdutès, jų neturejjo mažesniosios. Taip gal nurodomas jų kaip vyresniųjų statusas, o mažosios figūrèlès užèmė žemesnes pozicijas. Mažesniosios, matyt, vaizdavo jauniausius giminès narius, sėdinčius vyresniesiems savo protėviams - ant kelių. Tokiu būdu, fiziniu ryšiu, vyresnieji perduodavo atsakymus, išmintị ir stiprybę tiems, kas ieškojo pagalbos ar patarimo.

Straipsnyje kritikuojamas tiek ginocentrinių, tiek androcentrinių požiūrių naudojimasis tais pačiais archeologiniais radiniais atskiros hipotezès įrodymui. Abi kryptys radiniais naudojasi kaip įrankiu nustatyti natūraliam vyrų ar moterų dominavimui, siekiančiam akmens amžių. Neatsižvelgiant ị jų turinị, abiems pozicijoms būtina archeologinè medžiaga, kad būtų galima istoriškai pagrịsti, jog atitinkama visuomenès forma yra „pirmapradè, 
buvusi toje vietoje nuo pat pradžių“. Daugelis šių argumentų ir sampratų yra nepagrịsti, taikant naujausių laikų medžiagą priešistorès tyrimams. Abiem požiūriams trūksta istorinio pagrindo, o tekstuose taikomas atvirkštinis seksizmas. Be to, šie pavyzdžiai neapsiriboja vien paleolito ir neolito laikotarpiais archeologijoje. Šis trūkumas yra pagristas struktūrine problema, iškilusia archeologijos ir susijusių mokslų, kaip akademinių disciplinų formavimesi XIX a. istorizmo dvasia. Tyrimuose nepakankamai atskleista intelektinè disciplinų istorija, neištirtos tradicinès interpretacijos, tarp jų ir lyčių stereotipai. Dažnai šios interpretacijos nekritiškai plètojamos ir toliau.

Nors M. Gimbutienè laikoma viena pagrindinių matriarchijos temos tyrejuu, iš tiesų ši tema buvo pradèta kalbèti dar XIX a. Didelę ịtaką turèjo $1861 \mathrm{~m}$.
J. J. Bachofen darbas Das Mutterrecht. Jo poveikis akademinei bendruomenei ir bendrajam išsilavinimui buvo juntamas iki pat XX a. IV dešimtm., kai vyravo nuomonè, jog visų priešistorès visuomenių organizacija turèjo būti pagrịsta matriarchatu. J. J. Bachofen studija ir M. Gimbutienès darbai darè itaką ivvairias disciplinas ir tarptautinius sociopolitinius bei religinius judejimus. Be to, $M$. Gimbutienès idejos ịkvèpè kai kuriuos žmones leistis ị piligrimines keliones aplankyti archeologinių vietovių, minimų jos darbuose. Mokslininkès kūryba ir asmenybė veikè antrosios bangos feminizmą Jungtinèse Amerikos Valstijose ir iki šių dienų išlieka reikšmingi Vokietijos feminizmo ir matriarchato tyrimams bei postsocialistiniam Lietuvos moterų judèjimui.

Gauta: 20210421 Priimta: 20211007 